\title{
TRADICIJSKA TRGOVINA I SAJMOVI
}

Tihana RUBIĆ

Institut za etnologiju i folkloristiku

Šubićeva 42, 10000 Zagreb

\section{UVOD}

$\mathrm{T}$ rgovina na sajmovima, te izvan njih, bila je neophodan način distribucije i opskrbe različitim proizvodima na području Krivoga Puta, kojih je u okviru bližega zemljopisnoga područja nedostajalo. U poglavlju će biti riječi o trgovinskim aktivnostima na području Krivoga Puta, na relacijama: krivoputsko područje - Senj, krivoputsko područje - Otočac i krivoputsko područje - Brinje. Otočac i Brinje predstavljali su za područje Krivoga Puta najvažnija sajmena mjesta u razdoblju između dva svjetska rata, nakon Drugoga svjetskog rata te djelomično sve do danas. ${ }^{1}$ Ipak, nakon sedamdesetih godina 20. stoljeća intenzivna prodaja i trgovinska komunikacija u općini Krivi Put preusmjeruju se velikim dijelom sa spomenutih sajmova na otkupnu stanicu u Podbilu (naročito za otkup domaćih životinja, blaga), a prodaja pojedinih artikala od tih godina postupno potpuno nestaje.

U etnološkoj je literaturi ova tema općenito nedovoljno zastupljena, a na području Krivoga Puta još uvijek nije u cijelosti istražena, premda je trgovina, kako u okviru sajmova tako i izvan njih, bila važna dnevna, tjedna ili mjesečna aktivnost te izvor prihoda. Primjerice, značajne dnevne prodaje koje su se odvijale u gradu Senju bile su: prodaja mlijeka koje su u Senj donosile Bunjevke - mljekarice, te prodaja drva koja su u Senj dovlačili muškarci Bunjevci. Sajmovi su se, s druge strane, održavali jedanput tjedno i moglo je proći i nekoliko mjeseci a da pojedinačna obitelj nije imala potrebe za odlaskom na sajam. No, kako su ljudi na sajam dolazili iz različitih bližih i daljih lokaliteta is obzirom na slabo rodno tlo senjskoga zaleđa, ukupna trgovinska razmjena dobara predstavljala je vrlo živ segment svakodnevice na krivoputskome i širem okolnom području. Na taj su se način stanovnici snabdijevali neophodnim namirnicama i blagom. U ovom se poglavlju razmatraju raznovrsni aspekti trgovine, sajmova, prodaje i kupnje proizvoda, stoke i usluga na sajmovima i izvan njih koji su bili istraživani u lokalitetima krivoputskog područja: Alan, Francikovac, Krivi Put, Rusova Draga, Šojatski Dolac i Veljun, te u Senju, Švici, Krasnom i Kuterevu.

Mara Hećimović-Seselja u monografiji o selu Ivčević Kosa (1985) donosi opsežan prikaz tradicijskog života tog ličkog sela, no bez zasebnoga poglavlja o trgovini. Neki se podaci ipak, na temu trgovanja i puteva kojima se prolazilo, mogu pronaći pod poglavljem Promet. Tako se, primjerice, spominje da su Ivčevići svake srijede (sajmeni dan) kao nakupci stoke za vojsku redovito dopremali ugojene ovnove i jarce za vojsku u Otočac, a volove su otpremali iz Senja za vojsku u Trst i na Rijeku (1985:76). Takvi podaci mogu dati značajan uvid u kretanja šira od geografskog okvira krivoputskoga područja te pomoći u sastavljanju potpunije predodžbe o pravcima kretanja i lokalnim skupinama koje su iz trgovinskih razloga prolazile krivoputskim područjem prije i poslije Drugoga svjetskog rata.

Ante Rukavina u jednom od svojih radova, povijesnim pristupom obrađuje povezanost Senja i zaleđa razmjenom dobara te ukazuje: Senju je njegovo zaleđe bilo važna okosnica s kojom se, a i još daljom unutrašnjošcu, odvijala razmjena dobara i prije nego je Senj postao najveća robna luka sjevernoga hrvatskog primorja (1993b:223). U drugom tekstu donosi podatak i o tomu da Senj tijekom 19. stoljeća sustiže Rijeka $u$ trgovinskim poslovima, jer njezina željeznička veza s Europom ubrzava protok robe i ljudi, i Senj počinje naglo sužavati svoju gospodarku djelatnost. (Ibid. 1993a:215)

Tekst je u izmijenjenom obliku prvobitno objavljen u Senjskom zborniku. Vidi: RUBIĆ, Tihana (2004). 
Milana Černelić u svom novije objavljenom radu u Senjskom zborniku, pišući o dvjema zadružnim obiteljima na području Krivoga Puta, navodi korisne podatke o proizvodima koji su, prije i poslije Prvoga svjetskog rata, prodavale obiteljske zadruge Tomljanović-Puljiz (Podbilo) i Prpić-Grgajice (Kosove Buljme) (2000b:199-216). Tako navodi podatak da je za trgovinu bio zadužen gospodar kuće, a da su se zadružni proizvodi prodavali u Senju, Brinju ili Otočcu. Spominju se i proizvodi koji su mogli biti kupljeni u navedenim zadrugama (Ibid.:210). Svi ti podaci mogu biti značajno polazište općenito pri daljnjem istraživanju trgovine na krivoputskome području.

Za temu Trgovina i sajmovi postoji i relevantna Upitnica Etnološkog Atlasa (UEA), ${ }^{2}$ pod nazivom: Sajmovi (vašari), tema br. 105, prema kojoj je tema istraživana šezdesetih godina 20. stoljeća. U okviru Upitnice obuhvaćena su pitanja o vremenu i povodu održavanja sajmova (npr. vezanost uz crkvene svečanosti), lokalnom nazivlju za sajmove, proizvodima i trgovanju stokom na sajmovima, o ponašanju i radnjama prilikom prodaje i dogovaranja oko cijene, o načinima potvrđivanja sklopljena dogovora, o postojanju razmjene (trampe), o udaljenijim mjestima kamo se stoka gonila na prodaju i sl. ${ }^{3}$ Pomoću navedenih upitnica tema sajmova istraživala se za lokalitete Vratnik, Krivi Put, Jurjevo te nekoliko lokaliteta koji ne pripadaju području općine Krivi Put, ali s obzirom da su prostorno najbliži području Krivoga Puta, predstavljaju vrijedan izvor podataka za daljnja komparativna istraživanja. To su lokaliteti: Crni Kal, Konjsko (Karlobag), Medan (Gospić), Bušane (Gospić) u kojima se tema sajmovanja istraživala također šezdesetih godina 20. stoljeća 4 . Podaci na Upitnici pod nazivom Sajmovi vrlo su šturi i u Arhivu, u kojem su Upitnice pohranjene, ne nalazimo podatke za sve spomenute lokalitete ${ }^{5}$. Stoga ću u daljnjem tekstu navoditi i komparirati samo podatke iz Upitnica na koje, prilikom vlastitog terenskog istraživanja teme sajmova i trgovine, nisam naišla, ili koji se međusobno razlikuju.

U velikim etnološkim pregledima, primjerice Hrvatska etnografija (1998) i Hrvatska tradicijska kultura (2001), teme sajmova i trgovine tek su spomenute, najčešće u okviru teme Stočarstvo te u poglavljima o obrtničkoj proizvodnji, primjerice, Lončarstvo. No, ne postoji zasebno poglavlje ili odlomak koji bi se odnosio na temu trgovanja, trgovinskih komunikacija, sajmova, načina pribavljanja ili razmjene blaga i robe kupovinom i prodajom.

Aleksandra Muraj u poglavlju Obradba kože i roga spominje opančare koji su svoje proizvode obično nudili na prodaju na seoskim sajmovima (Muraj 1998:97), a u pregledu Hrvatska tradicijska kultura u poglavlju Prehrambene tradicije piše o seoskoj prehrani, navodeći kako se ista sastojala većinom od proizvoda domaćeg poljodjelstva (Ibid. 2001:295), navodeći to kao svojevrstan prijepis vlastitih resursa (Ibid.), a da se tek manji dio nabavljao kupnjom ili razmjenom. U istom poglavlju spominju se i proizvodi od kravljega mlijeka (Ibid.). Ipak, ostaje pitanje kako su ljudi uopće dolazili do blaga od kojega su mlijeko dobivali te ga dalje prerađivali. Dalje, ne nailazimo na podatke o načinima pribavljanja namirnica kupnjom ili razmjenom (Ibid. 109-114).

2 Upitnice Etnološkog atlasa (UEA) pohranjene su u Arhivu Odsjeka za etnologiju i kulturnu antropologiju Filozofskog fakulteta u Zagrebu.

3 Dobiveni podaci iz navedene upitnice uglavnom se poklapaju s onima dobivenim tijekom istraživanja provedenih na Krivome Putu 2004. i 2005. godine, no podaci iz Upitnice vrlo su nedostatni i šturi, često tek u vidu potvrdnog ili negativnog odgovora te mogu poslužiti tek kao polazište za detaljnija istraživanja. Prilikom terenskog istraživanja na Krivome Putu 2004. i 2005. godine ispitivanje je vršeno prema proširenoj upitnici, prethodno pripremljenoj za krivoputsko područje, no, prilikom sastavljanja šire upitnice, polazilo se od navedene UEA.

4 Nekom budućom prigodom bilo bi vrijedno komparativnim pristupom analizirati širi opseg lokaliteta iz Upitnica na temu sajmova. Takav pregled podataka dao bi uvid u temu na većem području te bi se podaci sagledali u širem prostornom kontekstu.

5 Upitnice za lokalitet Krivi Put nije pronađena prilikom pretraživanja Arhiva 2007. godine; zametnuta je ili izgubljena.

6 U poglavlju Stočarstvo također nema podataka o trgovanju blagom, o trajbarima (unajmljenim goničima blaga), sajmovima ili zadružnim otkupnim stanicama na kojima se blago kupovalo i prodavalo, niti o kretanjima potaknutim potrebom za trgovinskom razmjenom blaga. $\mathrm{U}$ istom pregledu autorica donosi ipak zanimljiv podatak o korištenju volova i konja za prijevoz, tegljenje. 
Jasna Čapo Žmegač u dijelu spomenutoga pregleda Hrvatska etnografija, Svagdan i blagdan hrvatskog puka (1998) govori o selu kao maloj, povezanoj socijalnoj zajednici unutar koje se ostvarivao najveći broj društvenih i životnih potreba, te spominje migracijska kretanja i promjene koje na selo unose industrijalizacija, trgovina i razvoj sredstava prijevoza. No, pored tih faktora, zaključuje, selo (je) za svoje stanovnike predstavljalo temeljni društveni prostor, prostor unutar kojega se uspostavljao najveći broj kontakata pojedinaca i obitelji i unutar kojega su ljudi provodili veći dio života (Čapo Žmegač 1998:280), a među komunikacijama koje su prelazile granice sela bili su, kako uočava ista autorica, gospodarski kontakti s drugim seoskim ili gradskim zajednicama (Ibid.), primjerice, sajmovi i odlazak na sezonski rad.

Nadalje, u potpoglavlju Doseg komunikacija izvan seoske zajednice, u istom pregledu, autorica uočava važnost trgovine u okviru šireg područja nekoliko zajednica, koja je, prema autorici, bila privilegirano mjesto susreta s drugim seoskim i gradskim zajednicama (Ibid.:293), a susrete nisu priječile ni kulturne, ni društvene, ni vjerske, ni etničke razlike (Ibid.).

Tako je, primjerice, vezano za područje Krivoga Puta, postojala trgovinska razmjena dobara između bunjevačkoga stanovništva senjskog zaleđa s (kulturno i klasno različitim) stanovništvom grada Senja. Bunjevke mljekarice koje su na prodaju u Senj nosile svježe mlijeko ${ }^{7}$ primjer su izvanlokalnih trgovinskih komunikacija (Muraj 2001:114). U knjizi Hrvatska tradicijska kultura A. Muraj navodi takav jedan opći podatak da su seljaci u blizini gradova opskrbljivali urbano stanovništvo mlijekom, svježim sirom i vrhnjem, suhim sirom i maslacem (Ibid.). To je bila prilika u kojima se uspostavljala praksa susreta i doticaja Bunjevaca krivoputskoga područja s građanima Senja, sa snažno prisutnom i u kazivanjima isticanom diferencijacijom i identifikacijom $M i-O n i$, na temelju uočljivih kulturnih različitosti. ${ }^{8}$

Naposljetku, etnološki radovi o tzv. neformalnoj, "sivoj”, ekonomiji (alternativno trgovanje) (Muraj 1990) pokazuju izrazit manjak sustavnoga bavljenja temom. Jednokratna domaća etnološka istraživanja te tematike (Muraj 1990; Rubić 2004) tek inicijalno nude smjernice za daljnje sustavno proučavanje tradicijskih uporišta, običajnih postupaka i organizacije kupoprodajnih aktivnosti na sajmovima tijekom 20. stoljeća, koji nerijetko predstavljaju alternativu (nepostojećem) formalnom zaposlenju. U tom smislu također, sajmovi i trgovanje predstavljaju relevantnu temu budućih, etnološki usmjerenih istraživanja.

\section{ODLAZAK NA SAJMOVE}

\subsection{GDJE SU BILI SAJMOVI}

Clavni sajmovi održavali su se u Lici - Brinju (ponedjeljkom) i Otočcu (srijedom). Najintenziv-

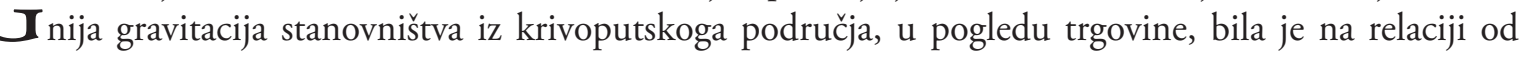
senjskoga zaleđa prema dvama spomenutim sajmenim mjestima. ${ }^{9}$ Iako su među stanovništvom najčešće spominjana i najpoznatija upravo ta dva sajma, trgovina je bila usmjerena također i na druge smjerove i lokalitete: primjerice, kretanja trgovaca iz Bosne (Bihać, Škrljevo) i Dalmacije, prema spomenutim dvama sajmenim mjestima. Zatim, iz Brinja i Otočca gonilo se blago do Crikvenice, Novog Vinodolskog, Rijeke pa čak i do Trsta. To je važan pokazatelj da su kretanja bila mnogostruka te da su svi ti pravci tvorili zanimljivu trgovinsku, komunikacijsku mrežu na području Krivoga Puta i šire. Karlovac je također bio značajno sajmeno mjesto na koje se iz Krivoga Puta ${ }^{10}$ još sedamdesetih godina 20. stoljeća odlazilo

Taj podatak možemo potkrijepiti primjerom Bunjevki iz zaleđa Senja koje su mlijekom i mliječnim proizvodima opskrbljivale grad Senj. Više o mljekaricama bit će govora u nastavku poglavlja o trgovini i sajmovima u ovoj monografiji.

8 Vidi o tome opširnije u radu: Škrbić-Alempijević 2004.

9 O smjerovima, točkama i odredištima tih kretanja valjalo bi narednim istraživanjima prikupiti još podataka.

10 Kod kazivača: Ivana Butkovića Gare iz Alana; Rudolfa Prpića Švorca iz Podbila; Branka Tomljanovića Ropete iz Krivoga Puta i Nene Vukelić iz Krivoga Puta. 
kupovati prvenstveno konje: Pokojni Ivan Ropeta je dva dana gonio konje iz Karlovca, iša je po ovom putu, zanoćivao bi. Kad bi dobrog konja kupio, selo bi se išlo divit, pa dobar ovaj, pa bi tražili manu, su se seljaci okupljali, to je bio doživljaj, pa - kakvo kopito, kakvi bokovi, griva, kakvi rep, znate kak'već to ide ${ }^{11}$; odnosno: Znam ja po Srećku starom, on je zna ić u Karlovac. Iz Alana su nekad znali ići u Karlovac. Valjda je bija veći izbor, ljudi su nekad išli i od gušta i od želje i potrebe. To se stari Srećko zna spremat. ${ }^{12}$ Po konje se odlazilo i u Slavoniju, ${ }^{13}$ Bjelovar i Zagreb, kamo bi konjari (stanovnici sela s područja Krivoga Puta koja su imala konje - ponajviše Alanari) išli kupovati teže konje za kirijanje - izvlačenje drva iz šume. Iz krivoputskoga se područja zatim znalo odlaziti i na sajam u Gospić, ${ }^{14}$ a kao sajmeno mjesto u kojem su se nabavljale svinje spominje se često Slunj. ${ }^{15}$

Sajmovi su se održavali jedanput tjedno. Na sajam bi se išlo kupiti ili prodati što se naumilo te bi se odmah potom vraćalo kući. Sajam se najčešće spominje kao odredište na koje se rado odlazilo: To je za ove krajeve bio takorekoć blagdan. Sve se slivalo taj dan na sajam. Il' je gonio, il nije gonio šta, to bi posjećivao, imao je neku orijentaciju kako će prodati i za koga će prodati. ${ }^{16}$

\subsection{KAKO SE IŠLO NA SAJMOVE}

$\mathrm{N}^{2}$ a sajmove se najčešće pješačilo ili bi se nekoliko ljudi dogovorilo da zajedno putuju jednim kolima. ${ }^{17}$ Išlo se tzv. bijelim putem, neasfaltiranom, brdovitom i vijugavom cestom, a putovalo bi se noću kako bi se rano ujutro stiglo na sajam, ${ }^{18}$ di je bilo ravno, tu se poveze na kolima, al di je bilo uzbrdo, tu side s kola, tako da bi konjima olakšao. ${ }^{19}$

U Otočac se išlo najčešće zaprežnim kolima jer je put iz područja Općine Krivi Put bio znatno dužii, ${ }^{20}$ no, primjerice, čak se iz Veljuna znalo pješačiti do sajma u Otočcu. Otac kazivačice iz Veljuna, prisjeća se ona, na sajam je kretao dan ranije, popodne, prenoćio bi kod poznatih u nekom od sela, rano ujutro stigao na sajam, a do podne obavio poslove i vraćao se pješice natrag. ${ }^{21}$ Nadalje, kazivač iz Krivoga Puta prisjeća se: Islo se rano ujutro, niste mogli ić u Brinj u 7 sati, pogotovu ujesen, rano, išlo se u 4 sata, 5, da dođeš u Brinj u 7, 8 sati, već je kasno, nećes prodat, nećes kupit, nije bilo auta, to se sve išlo pješice. ${ }^{22}$ Kako bi stoga dijelom prikratio put, koristile su se ustaljene prečice koje su presijecale glavne krivudave putove. Prečice su se u vremenu prije i za Drugoga svjetskog rata koristile kada se pješačilo, primjerice, u pratnji natovarenoga

11 Branko Tomljanović Ropeta, Krivi Put.

12 Nena Vukelić, Krivi Put.

13 Budućim terenskim istraživanjima trebalo bi precizirati u koje se lokalitete u Slavoniji išlo kupovati konje.

14 Mara Krmpotić Brnde, Veljun. Također, u Upitnicama UEA nailazimo na podatak da se iz Vratnika odlazilo po dobre konje u Benkovac, Gospić i Karlovac (UEA, Fd 422/562).

15 Rudolf Prpić Švorac, Podbilo.

16 Ivan Butković Gara, Alan. Iako govori u trećem licu jednine, ne misli na neku konkretnu osobu, već općenito, što se iščitava iz tijeka razgovora (transkribirala i tonski zabilježila: T. R.)

17 Ivan Krmpotić iz Šojatskoga Dolca je, primjerice, spomenuo kako je kao dječak s majkom znao odlaziti u Brinje na sajam iz Šojatskog Dolca te da su pješice gonili kravu ili išli uškopiti konja pastuva veterinaru u Brinje.

18 Marija Prpić Nikolčina iz Francikovca spominje primjer vlastitog iskustva pješačenja u Senj, te da je iz Francikovca pješice put trajao jedan sat vremena upoprijeko. Pješice je, kaže, znala ići i u Brinje na sajam, ali do puno udaljenijeg Otočca ipak se vozila kolima.

Kazivačica danas živi u Francikovcu.

19 Milan Tomljanović Periša, Zamalić.

20 Ivan Krmpotić iz Šojatskoga Dolca, primjerice, navodi podatak o udaljenosti od 15 km od Krivoga Puta preko Žute Lokve do Brinja te udaljenost od $46 \mathrm{~km}$ od Krivoga Puta do Otočca.

21 Eleonora Prpić Hela, Veljun.

22 Branko Tomljanović Ropeta, Krivi Put. 
magarca, ${ }^{23}$ dok se kolima moglo ići isključivo glavnim cestama. Cestom se išlo od Alana preko Krivoga puta, zatim na Prokike gdje bi se izlazilo na cestu preko Kapele, odakle je lijevi krak vodio prema Brinju, a desni prema Otočcu. To su bile dvije glavne ceste za područje Krivoga Puta. ${ }^{24}$ Od Alana do Senja išlo se pješice prečicom. Glavnim putom putovalo se 5 do 6 kilometara, dok su za ostatak puta (preostalih desetak kilometara) korišteni prečaci. Prelazilo se $s$ jedne serpentine na drugu, poprečnim putem, umjesto kruženja vijugavom glavnom cestom.

Nakon Drugoga svjetskog rata tri do četiri prečaca bilo je kod Klarićevca, na putu što vodi iz Senja i oni su se često koristili prilikom gonjenja drva u Senj. ${ }^{25}$

\subsection{HAJDUCI}

Driče o hajducima, ajducima, poznatim pljačkašima trgovaca i ostalih koji su išli prema sajmu ili se sa - sajma vraćali, i danas predstavljaju živ društveni segment jer lokalno stanovništvo iz područja Krivoga Puta i danas vrlo rado prepričava priče o hajducima, ${ }^{26}$ vezujući ih uz temu trgovine na ovom području i pritom ih naglašavajući kao veliku opasnost na putovima (Sl. 1).

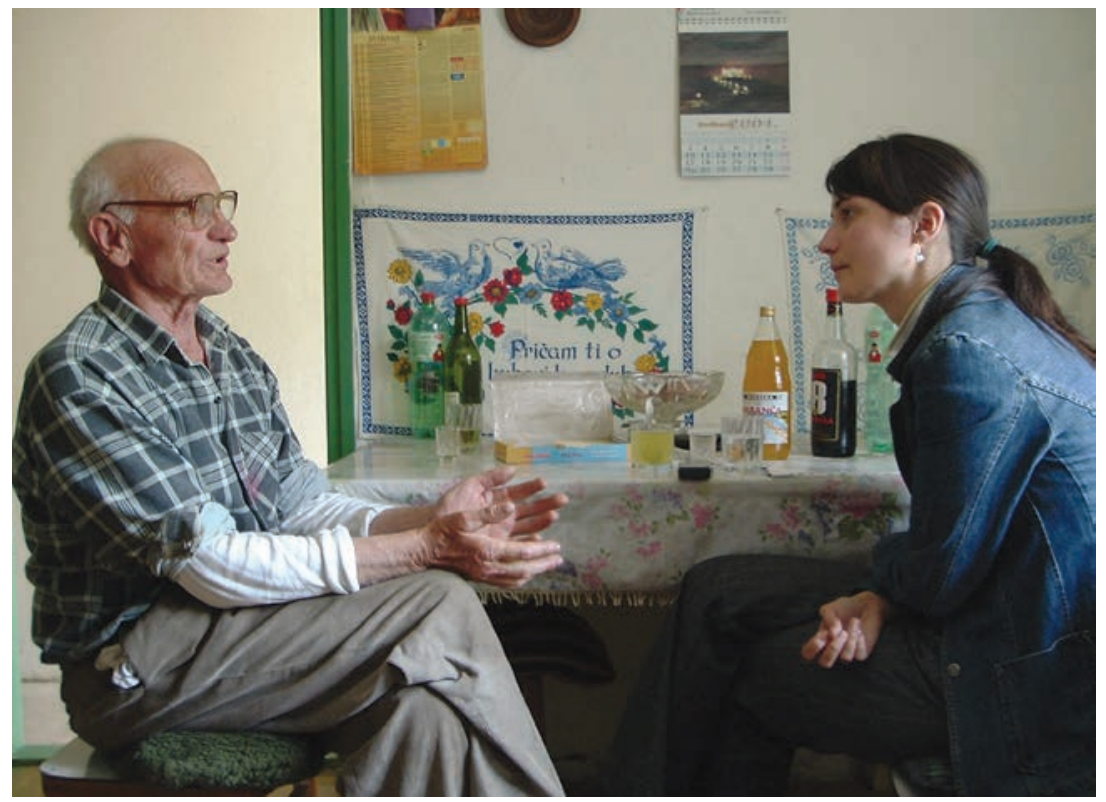

Slika 1: Gornji Veljun, autorica ovog poglavlja razgovara s kazivačem Milanom Prpićem Zekonjom u njegovoj kući; snimila: Marija Brajković, svibanj 2005.

Slušajući priče o hajducima, moglo bi se lako pretpostaviti kako kazivači pripovijedaju priču iz vlastitoga iskustva, s obzirom na slikovitost prepričavanja. Tomu zasigurno pogoduje oblik pripovijedanja u formi šala u stihovima, tzv. catara, ${ }^{27}$ u svezi kojih je zabilježeno zanimljivo kazivanje: Ovaj naš Šolić je

23 O transportu i transportnim pomagalima vidi šire u zasebnom poglavlju ove monografije, autorice Danijele Birt.

24 Ivan Butković Gara, Alan.

25 Milan Tomljanović Periša, Zamalić.

26 Kazivači vrlo slikovito i određeno prepričavaju događaje, napade i imena hajduka, No, na upit kada je hajduka bilo, ispostavlja se da su harali krivoputskim područjem za vrijeme stare Jugoslavije, prije Drugoga svjetskog rata, te da za njih kazivači znaju tek iz priča starijih.

27 Catare su, prema tumačenju stanovništva, opisi nekog regionalno ili lokalno poznatog događaja, od strane nekog od tamošnjih ljudi; šale, koje su imale karakter ogovaranja te su se opetovano, javno, koristile i to u formi rimovanih stihova. Primjerice, zabilježeno je lokalno tumačenje: Ima tih stihoklepaca koji su to bacali, sve živo, svaki catare. To 
imo, bio je nakupac i bio je prekupac, on je prodavao, i taj Gara je bio isto ovaj čuveni, on je isto bio trajbar. I oni su išli i isto kad ih je Prpić uhvatio, ajde da skrene pozornost sa...sebi, kaže: "Na Prpića namiguje Gara, Šoliću u cipeli para”, i Šoliću je ovaj ušo i cipelu i odnio pare, normalno. To je tako pjesma bila, da. Ljudi su to smislili, ljudi to brzo bace u stihove. ${ }^{28}$ Prethodnu priču potvrđuje kazivanje kazivača iz Alana: Jovo Čaruga $i$ Mali Prpić ubili su čovjeka, na putu izmedu Brinja i Krivog Puta. Mali Prpić je ubio Perjana, jednog čovjeka lopatom, to je bilo trideset $i$ koje godine. Glasoviti mali Prpić, banda Čarugina i Jovo Čaruga dočekali su trgovce u borovoj šumi pokraj Otočca. Prije Drugog svjetskog rata je meni otac pripovijeda da je jedan čovjek tako naišao na njih i oni su ga tražili hrane. On se suprotstavio i ubili ga. ${ }^{29}$

Podatak o Čarugi i slučajevima kada bi hajduci znali presresti i pokrasti trgovce široko je rasprostranjen i znan. Tako je primjerice zabilježeno još jedno kazivanje o istoj dvojici hajduka i spomenutom nemilom događaju: Čaruga se zva Prpić, on je baš bija Krivopućan. Između Krivog Puta i Prokika su dočekali trgovce i opljačkali im novce. Inače ovako između sebe, seljani su se toga Čaruge bojali, jer taj Čaruga je jednom njih dočeka. Znalo bit po više ljudi, pet, šest kola, grupno otidu, jer da ih neće dočekat hajduci. To je bilo za vrijeme stare Jugoslavije, a poslije otkad su Čarugu uhvatili, poslije rata, toga nije bilo. Nije on bio samo na ovom području, on je po cijeloj Jugoslaviji bija. ovaj je dočeka njega, mislim da je iša iz Brinja i sjedio je i jeo je pile, kokoš, a ovaj kaže: Daj mi, počasti me malo, a ovaj kaže: E, nije to bašza svakoga. A ovaj: Šta nije za svakoga? Njegovu sjekiru i ubije ga na licu mjesta. ${ }^{30}$ Prema kazivanju iz Veljuna ubijeni čovjek bio je iz Pavelića, a ubijen je na putu iz Brinja, dok se vraćao sa sajma: sjeo je i nosija sobom kokošpečenu i jeo. Čaruga je doša', ili Prpić, i pita njega 'oće li mu dat'. On je reka' da mu neće da’t i on ga je zato ubia i ostavi'a i njega i kokoš, nije htija (smije se). ${ }^{31}$

Područja na kojima su hajduci često presretali trgovce bila su Prokike i Lisičine. Prema kazivanju iz Veljuna, mjesto na kojemu je postojala potencijalna opasnost od hajduka nazivalo se pijana jaruga: Ideš kroz šikaru, žbunje, gore po planinama našim, na Krivom Putu. Ne znaš k’o tebe sa strane gleda pa su stari vikali: Nemojte k pijanoj jarugi ić! To je jedna duboka uvala, zove se jaruga, pijana jaruga, jer uvijek je, navodno, ne'ko u njoj, al' sad jel' bio? Vjerojatno su nekoga vidjeli ${ }^{32}$

Kazivačica rodom iz Vrataruše navodi kako joj je svekar pričao o hajducima te se sjeća priče o tome kako su ubili jednog trgovca koji je trgovao s volovima i pješice ih gonio i u Rijeku, Trst, s Udbine i iz Otočca. Potom pojašnjava kako je svekar (otac njezina supruga) rođen 1894. ili 1896., a da se navedeni događaj zbio ranije, u 18. stoljeću. Navedeni nam podaci daju mogućnost preciznijega vremenskog određenja prisutnosti opasnosti od hajduka. Potom se prisjetila još jednog slučaja ubojstva: Ubili su ga dole uz more, tamo se zove Sibil Kozica, tamo su ga ubili, veli: Veselite se bijele vile kad čujete, sutra ćete čuti tužne glase. I ta žena od toga čovjeka što su ga ubili, veli: Ode moj Perica. Bilo je svašta. ${ }^{33}$

\subsection{ODAKLE SU LJUDI DOLAZILI NA SAJMOVE}

$\mathrm{V}$ olovi su se, prije Drugoga svjetskog rata, prema narudžbi dotjeravali iz Bihaća. ${ }^{34}$ Gonili su ih trgovci, nakupci, pretršci na Škrljevo, gdje bi volove tovarili u vagone i slali za Italiju. Kupci toga blaga bili su već unaprijed dogovoreni. Pretršci su znali na sajmu kupiti 50 do 60 volova, platiti odmah te unajmiti

vam je ono kad se opiše neki dogadaj, ali u stihovima, ako je bila neka svadba, neka cura kojo se trebalo narugat, il' nekome, kom' bi trebalo ovako nešto nekog' isprovocirat', onda bi to bila ta catara. Catara je išla je k'o tajna pošta. (Branko Tomljanović Ropeta, Krivi Put).

28 Branko Tomljanović Ropeta, Krivi Put.

29 Ivan Butković Gara, Alan.

30 Ispričao Branko Tomljanović Ropeta, Krivi Put.

31 Milan Krmpotić Žutija, Veljun.

32 Eleonora Prpić Hela, Veljun.

33 Marija Prpić Nikolčina, Vrataruša.

34 Milan Tomljanović Periša, Zamalić. 
jednog ili više trajbara. Tako su se nazivali plaćeni ljudi koji bi iz Brinja i iz Otočca izgonili stoku do određenog mjesta. ${ }^{35}$

U lokalitetima Podbilo i Veljun zabilježen je podatak o tome da su na sajmove prije i poslije Drugoga svjetskog rata dolazili prodavači iz Bosne, ${ }^{36}$ otkuda su donosili robu na prodaju u Brinje i Otočac (Grčević 2000:297). ${ }^{37}$ Iz Bihaća ${ }^{38}$ i Kladuše ${ }^{39}$ u Otočac donosio se: kukuruz, ${ }^{40}$ krumpir (ujesen), ${ }^{41}$ grah, šljive, rakija ${ }^{42}$ i puno te hrane, ječam, kukuruz, p̌senica, zob, ${ }^{43}$ a gonili su se i volovi. ${ }^{44} \mathrm{U}$ Veljunu i Podbilu zabilježeno je sjećanje da je u Brinju bilo relativno malo prodavača iz Bosne, a kako se kukuruz, osim na sajmu, prodavao i po selima. ${ }^{45}$ U Otočac su ljudi iz Bosne (okolica Bihaća) od blaga većinom dolazili kupiti krave, janjad i ovce. ${ }^{46}$

TVeljunu je zabilježen podatak o nakupcima, prekupcima iz Dalmacije, koji bi na placu za goveda dolazili preko područja Krivoga Puta. ${ }^{47}$ Osim iz Dalmacije, na sajmove se također dolazilo iz Slavonije, Rijeke, Opatije i Pule, te sa svih strana je dolazilo iz ovih naših krajeva, Veljuna, ${ }^{48}$ Brinja, Jezerana, Polja, Švice i Otočca. ${ }^{49}$ Trgovci koji su dolazili iz Zadra i iz Splita još su i najbolje, Dalmatinci, platili. ${ }^{50}$

Od svih zaseoka krivoputskoga područja najviše konja bilo je u Alanu. ${ }^{51} \mathrm{U}$ vremenu iza Drugoga svjetskog rata pa sve do sedamdesetih godina 20. stoljeća (kada su počela velika iseljavanja Bunjevaca u $\operatorname{grad}$ Senj $)^{52}$ konji su se držali u selima: Alan, Podbilo, ${ }^{33}$ Šojatski Dolac, ${ }^{54}$ Krivi Put $^{55}$ i Vrataruša. ${ }^{56}$ Konjari

35 Podatak o tom nazivu, postojanju trajbara i opisu njihova posla zabilježen je kod svih ispitanih kazivača.

36 Antun Prpić Matin iz Veljuna navodi kako su Bosanci većinom kupovali krave, janjad i ovce. Rudolf Prpić Švorac iz Podbila, Antun Prpić Matin iz Veljuna i Marija Prpić Nikolčina iz Vrataruše donose podatke o Bosancima.

37 Zlata Tomljanović Pešina iz Krivoga Puta jedina spominje kako prodavači iz Bosne nisu prodavali kukuruz, nego da su to bili ovde domaći, a da izričito kukuruza malo se i prodavalo, te bi taj podatak trebalo detaljnije ispitati. Zanimljiv je istovjetan ovomu podatak koji J. Grčević navodi u monografiji Kompolje: S žitom i kukuruzom slabo se trguje, već se to potroši kod kuće. U nerodnim godinama trebaju, osobito kukuruz, i uvoziti. (Grčević 2000:297)

38 Prema kazivanju većine kazivača.

39 Ante Prpić Rus, Rusova Draga.

40 Ivan Butković Gara, Alan; Ante Prpić Rus, Rusova Draga; Milan Krmpotić Žutija i Mara Krmpotić Brnde, Veljun.

41 Ante Prpić Rus, Rusova Draga.

42 Antun Prpić Matin, Veljun.

43 Mara Krmpotić Brnde, Veljun.

44 Milan Tomljanović Periša, Zamalić.

45 Milan Krmpotić Žutija i Mara Krmpotić Brnde iz Veljuna naveli su taj podatak. Trebalo bi ispitati je li se prodavalo od kuće do kuće ili bi prodavač stajao na jednom mjestu ili se pak kretao po selu, vičući. Podatak o tome donosi i Rudolf Prpić Švorac iz Podbila. Zlata Tomljanović Pešina iz Krivoga Puta jedina spominje kako prodavači iz Bosne nisu prodavali kukuruz, nego da su to bili ovde domaći, a da izričito kukuruza malo se i prodavalo, te bi taj podatak trebalo detaljnije ispitati.

46 Antun Prpić Matin, Veljun.

47 Mara Krmpotić Brnde, Veljun.

48 Eleonora Prpić Hela iz Veljuna navodi podatak da se volove gonilo na sajam iz Veljuna. Veljun je jedno od sela krivoputskog područja gdje su se držali volovi, voli. Ljudi iz Veljuna nazivaju sami sebe, a tako ih zovu i ljudi iz drugih mjesta, volarima (različito od - konjara).

49 Milan Krmpotić Zekonja, Veljun.

50 Prema kazivaču Antunu Prpiću iz Veljuna.

51 Ivan Butković Gara, Alan.

52 O migracijama vidi više u zasebnom prilogu ove monografije, autorice M. Rajković.

53 Milan Tomljanović Periša iz Zamalića i Branko Tomljanović Ropeta iz Krivoga Puta.

54 Ivan Krmpotić, Šojatski Dolac.

55 Milan Tomljanović i Branko Tomljanović Ropeta.

56 Marija Prpić Nikolčina. 
iz Alana odlazili su na sajmove u Otočac ili Brinj, ali za teže, vučne konje, odlazilo se na sajmove u Karlovac, Bjelovar i Zagreb, gdje bi kupovali ili prodavali veće konje jer takvih nije bilo na sajmovima u Brinju i Otočcu. ${ }^{57}$ U Francikovcu i Veljunu ${ }^{58}$ držali su se volovi i za ta se sela govorilo da u njima žive volari. ${ }^{59}$ Volovi su služili za oranje, vuču sijena, ali i tovar drva u Senj. Za gonjenje drva trebalo je krenuti uvečer da bi se u grad Senj stiglo rano ujutro. S volima se nije moglo ići prečacem, tako da je put bio dug, a pored toga, prodaja u Senju nije uvijek bila zajamčena.

Zašto su neka sela na području Krivoga Puta imala konje, a druga volove? Među lokalnim stanovništvom iz Alana, Krivoga Puta i Vrataruše zabilježena su zanimljiva kazivanja koja se odnose na spomenute lokalitete: To se uobičajilo možda od davnine, jer oni su nekako prilagodili se, imali i bolju zemlju pa su se bavili isključivo poljoprivredom i vozili na volovima. Znate, kako je ko na šta naučio. Znate, da teško volu ako ga uzme konjar, jer će ga brže gonit i sve. Il lako konju ako ga uzme volar, on pomalo, lagano ide. Teško je kirijaša s konjima, da će on uzet volove pa ić s njima u šumu, to je rijetkost, to je težak posao, to je spor, mukotrpan. Konji, da. ${ }^{60}$

Pritom je zanimljiva distinkcija $M i-O n i$ u kazivanjima stanovništva krivoputskoga područja, primjerice: Mi smo konjari, a ovi gore okolo, oni su imali vole, a mi ne u Krivom Putu, ne volove. Moj tetak je imao vole, jer volovi nisu, mlitavi su, spori, tromi, onda bi se radilo s konjima ${ }^{61} \mathrm{Na}$ razini lokalnog identiteta kao označitelj simboličkog razdvajanja koristi se vrlo često upravo vještina obavljanja poslova uz pomoć različitih životinja - s jedne strane - s konjima (konjari), s druge strane s volovima (volari) i nastoje se istaknuti prednosti držanja jedne životinje naspram druge.

U Vrataruši su također držani konji. Zabilježeno je tako sjećanje na vlastito iskustvo rada i s volovima i konjima, ovisno o tome iz kojeg i u koje mjesto bi se djevojka udala, primjerice: Ja kad sam došla ovdje (Francikovac), radila sam sa volovim (sredinom 20. stoljeća), a tamo kod mojih (Vrataruša) bili su konji. Tata nije volio nikada ićs sa konji pa smo ja i sestra išle, među autima koji su drva vozili iz Vodice, Miškovice. Konji su se plašili i onda bi morale dobro paziti da ne bi na nas auto naletilo. ${ }^{62}$ Posao oko blaga smatrao se muškim poslom, te je navedeno kazivanje zanimljiv primjer kako su se i žene bavile poslom oko domaćih životinja, blaga. ${ }^{63}$

\section{SAJAM}

\subsection{ROBA NA SAJMU}

$\mathrm{D}$ va najvažnija sajma na području Krivoga Puta bili su Otočac i Brinj. Otočac je bio veći sajam, ali je bio i puno udaljeniji od krivoputskoga područja.

Sajmovi u Otočcu i Brinju imali su odijeljene dvije place - za robu (žitna placa) i za blago (stočna placa) ${ }^{64} \mathrm{Na}$ stočnoj placi prodavali su se volovi, krave, telad, svinje, konji, ovce, perad i sl. Iz Upitnice UEA doznajemo kako bi se prije gonjenja na prodaju stoku nahranilo, napojilo i očistilo. Na žitnoj placi prodavala se hrana, voće, živežne namirnice i ručne izrađevine. ${ }^{65}$

57 Prema kazivanju Ivana Butkovića Gare, Alan.

58 Milan Krmpotić Žutija, Mara Krmpotić Brnde, Veljun; Antun Prpić, Veljun i Eleonora Prpić Hela, Veljun.

59 Milan Tomljanović Periša, Zamalić i Branko Tomljanović Ropeta, Krivi Put.

60 Ivan Butković Gara.

61 Branko Tomljanović Ropeta.

62 Marija Prpić Nikolčina prisjeća se kako su se u Vrataruši (njezinom rodnom mjestu) držali konji.

63 Marija Prpić Nikolčina išla je u Brinje (pješice) i Otočac (kolima) na sajam po blago. Dalje u tekstu, u poglavlju Žene i muškarci na sajmovima i u trgovini izvan sajmova, bit će više riječi o muško-ženskim podjelama poslova.

64 Podatak da se prostor za prodaju blaga nazivao stočnom placom dobiven je od Ivana Butkovića Gare iz Alana i Milana Krmpotića Žutije iz Veljuna.

65 U Kompolju su drugačiji lokalni nazivi - na blaženom placu prodaje se blago, a na krušnom placu; živad, jaja, sir, maslo, slanina itd. (Grčević 2000:297), 
Na sajmu u Otočcu bio je velik izbor robe: U Otočcu ima robe, ma to - zamislit što ima, izbor veliki! ${ }^{66}$ i domaćih životinja: Ma sve se prodavalo, i kokoši, peradi, svinja, sve živo morete kupit na takvim sajmovima! ${ }^{67} \mathrm{O}$ veličini sajma i brojnosti goveda u Otočcu, prije Drugoga svjetskog rata, svjedoči, primjerice, i opis: Otočac je bio najveći sajam, tamo su znali dogonit, za vreme stare Jugoslavije, volova po stotinu, čak iz Bihaća su znali dotjerat vole i prodavat, nekad proda, nekad ne i vrati natrag. ${ }^{68} \mathrm{U}$ Brinju su bile dvije place - stočna, te druga placa, na kojoj se prodavala roba, primjerice: sjemenje, žito, maštele, kabli i burila. ${ }^{69} \mathrm{U}$ Brinju su, pored dviju odvojenih tržnica, od vremena stare (Kraljevine) Jugoslavije pa do Drugoga svjetskog rata, postojale i privatne trgovine povratnika Bunjevaca iz Amerike. ${ }^{70}$ Nakon Drugoga svjetskog rata, otvarale su se i državne trgovine koje su, po povratku s prekooceanskoga privremenog rada, također otvarali domaći ljudi: Dode iz Amerike pa otvori dućan. Od kravi i lanaca, potkova, vila, grabalja, robe, cipela, hrane je bilo svakakve, mješovita roba. Na dućanima je to pisalo. ${ }^{71}$

U Senju su također, prije Drugoga svjetskog rata, Bunjevci po povratku s rada u Americi, otvarali dućane mješovitom robom. Iz Amerike bi pristigli s određenim kapitalom kojeg bi ulagali u kupovinu kuće u Senju u prizemlju koje bi otvarali takav dućan.

Lončari su na sajmove u Brinje i Otočac dolazili iz Like (Kaluđerovac) ${ }^{72}$ i Bosne. ${ }^{73} \mathrm{Na}$ području Krivoga Puta lonci od pečene gline (gnjile), ručno izrađene glinene posude, bili su kupovani i korišteni za kiseljenje mlijeka te su se mogli kupiti na sajmovima u Brinju i u Otočcu. ${ }^{74}$ Pored ponude na sajmu, lončari su obilazili i sela na području Krivoga Puta, u kojima su prodavali svoje proizvode: Ovako, kol'ko proda, išao je od sela do sela, imao je konjiće, ja se sjećam, lončari su to neki kola i obloženo je to bilo slamom da se ne polupa. Al' njemu je bila potreba da proda. ${ }^{75}$

\section{2. ŽENSKII MUŠKI POSLOVI U TRGOVINI NA SAJMOVIMA I IZVAN SAJMOVA}

Ta sajmove su pretežno odlazili muškarci. Kako je sajam bio glavno mjesto trgovanja stokom, kupci 1 i trgovci bili su većinom muškarci jer se i u svakodnevnom životu posao oko blaga smatrao muškim poslom.

Međutim, zabilježeno je i nekoliko podataka da su i žene sudjelovale u takvim poslovima, iako ih i same smatraju muškima (Sl. 2). U Veljun su žene skroz od Crkvenice dolazile kupovati krave te bi znale i prenoćiti u Veljunu u privatnim kućama. ${ }^{76}$

Žene su na sajmovima većinom prodavale tkane ručne radove. To su bile Ličanke koje su izrađivale poznate biljce (tkane, vunene, tople pokrivače) koje su prodavale u Brinju i Otočcu. Žene su išle kupovati sitnije stvari u dućanu. Također, žena je znala odlaziti na sajam sama s djecom, ako bi ostala udovica ili za vrijeme dok su muževi bili odsutni, primjerice, na privremenom radu na nekoliko godina u Americi ili

66 Antun Prpić, Veljun.

${ }^{67}$ Branko Tomljanović Ropeta, Krivi Put.

68 Milan Tomljanović Periša, Zamalić.

69 Eleonora Prpić Hela, Veljun.

70 Vidi više o tome u zasebnom poglavlju ove monografije, autorice M. Rajković.

71 Milan Tomljanović Periša, Zamalić.

72 Podatke o lončarima trebalo bi upotpuniti narednim istraživanjima i kazivanjima o kretanju lončara do sajmova, Senja, i prilikom obilaženja sela na području Krivoga Puta.

73 Prema sjećanju Milana Krmpotića Žutije. S obzirom da za podatke o lončarima na sajmovima i izvan sajmova (prodaja po selima) nedostaje provjera kod većeg broja kazivača, nužno je budućim kontrolnim istraživanjima provjeriti dobivene podatke te detaljnije istražiti trgovanje lončarskim proizvodima na ovom području.

74 Marija Prpić Nikolčina iz Vrataruše donosi podatak o namjeni lonaca.

75 Ivan Butković Gara, Alan.

76 Antun Prpić Matin, Veljun. 


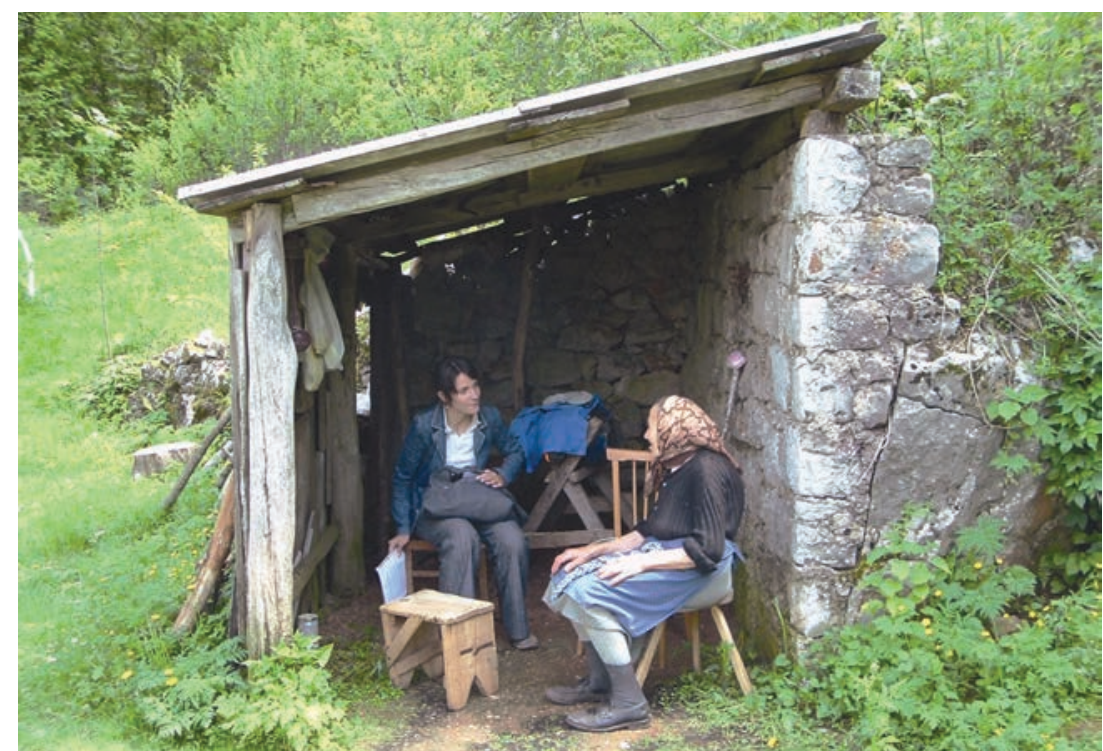

Slika 2: Gornji Veljun, autorica ovog poglavlja rągovara o ženskim $i$ muškim poslovima s Marijom Krmpotić Brnde, pod bajticom koja se nalazi u okucnici, ispred ulaza u kuíu; snimila Marija Brajković, svibanj 2005.

Kanadi. U tom slučaju neki bi joj muškarac iz sela pomagao pri kupovini na sajmu ${ }^{77}$ jer, ženska se uvijek raćunala - slabiji spol i slabije se ona i razumjela u konja il' kravu $i$ tako da uvijek je uzela nekoga iz sela koji je neśta više znao tako da je s njom iša i kupija je. ${ }^{78}$ Međutim, suprotan primjer je već spomenuto vlastito iskustvo odlaženja žene na sajam iz Vrataruše i Francikovca po blago. ${ }^{79}$

Prije Drugoga svjetskog rata, dok nije bilo tvorničkog mljekarstva, žene su sirile sireve, sušile ih na dimu te potom prodavale. ${ }^{80}$ Mjesta iz kojih su žene mljekarice, mlikarice, mlekarice odlazile prodavati sir i mlijeko u Senj bila su: Klarićevac, Alan, Podbilo, Krivi Put, Katići, Pavelići, ${ }^{81}$ Veljun ${ }^{82}$ te Vrataruša. ${ }^{83}$ Prije i nakon Drugoga svjetskog rata pa pretežno do pojave Zadružne otkupne stanice u Podbilu, žene iz krivoputskoga područja su na prodaju u Senj također nosile jaja, kiselinu ${ }^{84}$ i kokoš. Zarada je bila vrlo skromna jer je i količina robe koje je jedno domaćinstvo moglo proizvesti, a i žena na jednom magarcu dopremiti u grad, bila mala. Svoje proizvode žene nisu prodavale na sajmovima, već u gradu Senju i to svojim stalnim kupcima, mušterijama, kontama. Tradicionalna podjela poslova oko prodaje na muške i ženske, na one koji se odvijaju na sajmovima i izvan njih, može se uočiti iz kazivanja jednog od stanovnika iz Krivoga Puta, koji danas živi u Senju: Pretežno su muški išli, pretežno muški na sajmove. Pazite, muški su to, žene bi dolazile obično sa muževima, čuvale kola $i$ to, al’ muški su radili glavni posao. Kod nas nisu žene imale šta, ako su vozile mliko, vozile su u Senj same, to vam nisu one išle po sajmovima. ${ }^{85}$

77 Ivan Butković Gara, Alan.

78 Milan Tomljanović Periša, Zamalić.

79 Prema kazivanju Marije Prpić Nikolčine. Taj primjer predstavlja individualan otklon u tom kraju, ali bilo bi zanimljivo nadalje istražiti učestalost takvih iznimaka.

80 Ivan Butković Gara, Alan.

81 Milan Tomljanović Periša, Zamalić.

82 Milan Krmpotić Žutija.

83 Marija Prpić Nikolčina, Vrataruša.

84 Kiselina je naziv za kiselo mlijeko.

85 Branko Tomljanović Ropeta, Krivi Put. 


\subsection{LIKOVO I POGODBA BILI SU OBAVEZNO! ${ }^{86}$}

$\mathrm{N}^{2}$ a sajmovima se prilikom kupnje vikalo, cjenkalo i pogađalo. Podatak u literaturi o cjenkanju za stoku, kao ritualiziranom obliku robno-novčane razmjene, donosi Olga Supek kao primjer razmjene prilagođene životu lokalnih ljudi i njihovim suvremenim potrebama (Supek 1987:11-12) ${ }^{87}$. O. Supek tako slikovito opisuje: Na periodičnim stočnim sajmovima često se javlja (a zabilježen je i u zapisima s početka ovog stoljeća) neobični ritualizirani oblik cjenkanja za stoku koji je u stvari verbalna igra, duel izmedu dvojice muskaraca, praćen navijanjem okupljene publike. Glasno izvikivanje cijena, pljeskanje dlanom o dlan, povlačenje "protivnika" za ruku, pa čak i podcjenjivanje i izrugivanje upotrebom fiksnih verbalnih formula (...) (Ibid.:12)

U Veljunu je zabilježen podatak kako se na sajmu vrlo često moglo čuti: Jeftino dam da prodam!'Također je zanimljivo i šaljivo na koje su sve načine prodavači nastojali pohvaliti i prodati svoju robu prilikom prodavanja ili pogodbe. Oni koji su bili vješti u prodaji znali su tako dobacivati: Dabogda odavde ne vidjeh svoju kuću, ako ne daje 10 litara mlika! Ili: Dabogda ne oslijepio na oba koljena! Ili: Dabogda spav'o sa svojom Katom! (A Kata mu je žena). ${ }^{88}$

Dvije bi strane, dakle, nudile svoju cijenu te bi se postupno dogovorile oko cijene s kojom bi obje strane bile zadovoljne. Dogovor bi se potvrdio rukovanjem a najčešće bi tom prilikom bila prisutna treća muška osoba koja bi ruke presjekla i tako posvjedočila sklopljenom dogovoru. ${ }^{89}$

Cjenkanje, pogađanje, uvijek se spominje kroz smijeh, kao zabavni događaj, no istovremeno je riječ o ozbiljnom činu kupoprodajnoga procesa u kojem dolazi do konačnog ishoda o iznosu koji će jedna strana dobiti, a druga dati, na zadovoljstvo i suglasnost obiju strana. Prilikom sklapanja pogodbe neizostavno se izvodilo rukovanje, prilikom čega dlanovi trebaju što jače pljesnuti, zatim podizanje ruku i presijecanje ruku od strane svjedoka. Tim bi se radnjama simbolički potvrdilo ono što je prethodno izrečeno usmenim dogovorom. „Nemogućnost“ odstupanja od dogovorene cijene, nakon što je pogodba sklopljena, omogućuje i treća osoba u ulozi svjedoka, koja svojom gestom presijecanja ruku daje dodatnu važnost dogovoru i potvrđuje „nepromjenljivost“" sklopljenog dogovora ${ }^{90}$.

Na otkupnoj stanici u Podbilu nije bilo cjenkanja jer je cijena bila već određena od strane Poljoprivredne zadruge. Cijena teladi i goveda ipak bi varirala s obzirom na kvalitetu i težinu same životinje. Cijena bi se određivala vaganjem na velikoj zadružnoj vagi na otkupnoj stanici.

Nakon prodaje često se navraćalo u obližnju sajmenu gostionu gdje se pilo likovo. ${ }^{91}$ Tako se nazivala bilo koja vrsta pića koja bi se zajednički ispijala nakon sklopljene kupnje i prodaje. Pogodbe su bile neizostavan dio sajmova, o čemu svjedoči jedno od zabilježenih kazivanja: Kako nije bilo - pogodbi?! Ti tražiš toliko, ja toliko, onda ti je bilo uvik onih sa strane: Nemojte gledat, dajte mu jošte malo, a onaj viče: Daj ti malo! I tako, ciganija! ${ }^{92}$ Cjenkanje i sklapanje dogovora najčešće se opisuju kao dinamičan, zabavan događaj, primjerice: Uuuu, to sad kad gledate, to je doista smiješno, to je mahanje i oćešsa ovoliko, oćes za oniko... i onda se ruke obe digle i ovaj svoje, ovaj svoje ${ }^{93}$. Bilo je važno da ruke snažno pljesnu jer bi se time

86 Milan Tomljanović Periša, Zamalić.

87 Autorica zanimljivo opisuje cjenkanje na stočnom sajmu u Jastrebarskom.

88 Branko Tomljanović Ropeta, Krivi Put.

89 Ivan Butković Gara iz Alana: Uuuu, to sad kad gledate, to je doista smiješno, to je mahanje i..., oćeš za ovoliko, oćeš za oniko... i onda se ruke obe digle i ovaj svoje, ovaj svoje.

90 Isti opis cjenkanja i pogađanja nalazimo i u Upinici UEA, Fd 422/562, osim što se kod pijenja likova spominju i mišetari - u ulozi svjedoka, što nije zabilježeno prilikom terenskog istraživanja na području Krivoga Puta. Mišetari su se spominjali samo kao trgovci i niti jedan kazivač nije spomenuo ili istaknuo njihovu ulogu svjedoka prilikom pijenja likova.

91 Milan Krmpotić Žutija, Veljun i Branko Tomljanović Ropeta, Krivi Put.

92 Milan Krmpotić Žutija, Veljun.

93 Ivan Butković Gara, Alan. 
simbolički označio definitivan dogovor i dobro sklopljena pogodba. Obično likovim časti prodavač, koji poziva riječima: Ajmo popit likovo. ${ }^{94}$

\subsection{PRODAJEM TI KRAVU, NE PRODAJEM TI JASLE!}

Tzrečice također predstavljaju zanimljiv dio društvene kulture koji se prenosio usmenim putem, a koristile su se prilikom dogovaranja i nadmudrivanja oko prodaje. ${ }^{95}$

Prilikom prodavanja krave znalo se govoriti: Toliko ti daje mlijeka, al' prodajem ti kravu, ne prodajem ti jasle, treba je hranit. Jer obično su rekli naši stari: Krava daje mlijeko: kako je hraniš, tako će ti bit mlijeko. ${ }^{96}$ Zanimljiv primjer prodaje krave, zabilježen u Veljunu, jest slučaj kada je pritržac prilikom prodaje kravu suviše hvalio pa mu je netko bio rekao: Pa kad je tako dobra, onda je neću prodat! ${ }^{97} \mathrm{Na}$ području Krivoga Puta poznata je i uzrečica: Dobra krava se u svom selu proda. Ta se uzrečica koristila za blago, ali se njome, u okviru stereotipnih muških predodžbi, označavao i varljivi karakter potencijalne djevojke za udaju. $\mathrm{Na}$ spomenutu uzrečicu Dobra krava se i u svom selu proda, nastavlja se dio:...i dobra cura uda! ${ }^{98}$ Kad bi se djevojka udavala u drugo selo i ako se učinilo da je „sumnjivoga“ karaktera, govorilo se: Dobra krava ostaje u svom selu, to je staro pravilo. ${ }^{99}$

Ti primjeri zanimljivo pokazuju prenošenje trgovačke terminologije u područja društvenih i predsvadbenih običaja.

\subsection{GOSTIONICE, PRENOĆIŠTA}

Ta putovima prema sajmovima bile su gostionice u kojima su se trgovci i ostali, koji bi išli ponešto 1 kupiti ili prodati, odmarali, pojeli, popili ili čak noćili. Gostionice su zanimljiv element proučavanja trgovinskih kretanja jer mogu pomoći u sastavljanju mreže puteva kojima se trgovalo i komuniciralo i otkriti u kojim su se lokalitetima trgovci i ljudi na dolasku ili odlasku sa sajma zadržavali. Na području Krivoga Puta i šire dobro se znalo za pojedina mjesta - stanice, na kojima se moglo odmoriti i odsjesti. ${ }^{100}$ Te su gostionice imale štale za konje gdje bi, prilikom noćenja, konji bili nahranjeni sijenom. U te se gostionice nerijetko navraćalo na marende, no, one su se, pedesetih godina 20. stoljeća, mogle pojesti i $\mathrm{u}$ šatorima na sajmu gdje se pojelo $i$ dimilo. ${ }^{101}$ Većina kazivača stoga navodi kako se najčešće nije jelo po gostionicama, već da bi se, zbog neimaštine, češće sa sobom nosio skroman ${ }^{102}$ obrok, koji se sastojao od suve hrane, ${ }^{103}$ špeka (slanine u džepu ${ }^{104}$ ), kruha $(k r u v a){ }^{105} \mathrm{i} / \mathrm{ili}$ sira ${ }^{106}$, palente ${ }^{107}$ te koje jaje kuvano, u zavežljaju. ${ }^{108} \mathrm{O}$ vrlo skromnim prilikama, kada se često i nije imalo što ponijeti sa sobom na put, slikovito go-

94 Nigdje zasad nije zabilježen podatak da su se žene na taj način cjenkale, dogovarale, sklapale pogodbe ili likovim nazdravljale sklopljeni dogovor oko cijene.

95 Uzrečice bi trebalo dodatno opširnije istražiti prilikom idućega terenskog istraživanja.

96 Ivan Butković Gara, Alan.

${ }^{97}$ Milan Krmpotić Žutija, Veljun (smije se).

98 Milan Krmpotić, Veljun.

99 Prema riječima Branka Tomljanovića Ropete iz Krivoga Puta.

100 Ivan Butković Gara, Alan.

101 Ivan Butković Gara, Alan; Branko Tomljanović Ropeta, Krivi Put.

102 Marija Prpić Nikolčina iz Francikovca, rođena u Vrataruši.

103 Antun Prpić Matin, Veljun.

${ }_{104}$ Milan Krmpotić Žutija, Veljun.

${ }^{105}$ Ivan Butković Gara, Alan; Ante Prpić Rus, Rusova Draga; Milan Krmpotić Žutija, Milan Krmpotić, Veljun; Mara Krmpotić Brnde, Veljun i Antun Prpić Matin, Veljun.

106 Ante Prpić Rus, Rusova Draga i Antun Prpić Matin, Veljun.

107 Nena Vukelić, Krivi Put.

108 Ista kazivačica. 
vori kazivanje prema osobnom iskustvu: 'Ko je šta ima. Bila sam gladna, bez ičega. Moreš jedan dan izdržat i ne jest. Trgovci su bili ti koji su češće stajali u gostionama, prije i nakon Drugoga svjetskog rata, kada bi išli preko Veljuna, Prokika i Brinja prema Krivome Putu do Senja, Novog Vinodolskog i Crkvenice. Nisu uvijek noćivali u gostionicama, već bi na određeno vrijeme zastali, pojeli ponešto od onoga što su nosili sa sobom i potom krenuli dalje (Sl. 3). ${ }^{109}$

Česti gosti gostionica bili su i trajbari, ${ }^{110}$ koji su ustaljenim putovima išli jedanput tjedno, te najmanje tri puta mjesečno prema Rijeci. Na putu su imali svoje konte ${ }^{111}$ (već ustaljena mjesta na kojima bi zastajali), gdje bi katkad i noćivali.

U Brlogu ${ }^{112}$ se nalazilo, primjerice, poznato odmorište $^{113}$ čiji je vlasnik bio Ivica Vrzić, Ličanin. U toj bi se gostionici odsjedalo u slučaju kiše, a uz peć se mogla osušiti mokra odjeća. Pored gostionice u Brlogu, postojale su gostionice u Otočcu (u kojoj bi se i noćivalo), ${ }^{114}$ prenoćište u Senjskoj Dragi, ${ }^{115}$ gdje su boravili Ličani kad bi se vraćali iz Senja, te gostionice u Brinju (privatna), na Vratniku (vlasnika Tome Nigeša) i tamo po Grižanin, onda na Meji, gdje su ljudi noćivali sa blagom

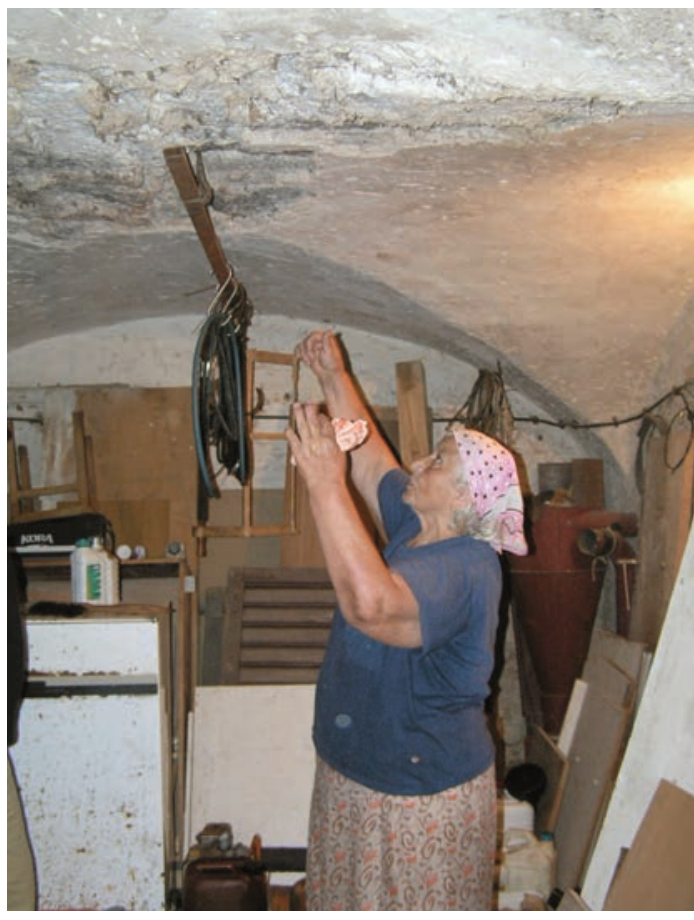

Slika 3. Francikovac, Marija Prpić Nikolčina pokazuje stropne volte unutar podrumskih prostorija u kojima se držalo vino za prodaju u nekadašnjoj gostionici; snimila Marijeta Rajković, svibanj 2005. u slučaju ružnog vremena. ${ }^{116} \mathrm{U}$ Klarićevcu se također nalazila poznata gostionica, koja predstavlja zanimljiv arhitektonski sklop, ${ }^{117}$ a poznata je pod imenom Cotina birtija.

U samome je gradu Senju, kod Odbora, također postojala gostionica, koja je bila državna, otvorena nakon Drugoga svjetskog rata. Tamo si moga' popit' i poplesat', bil je veliki Dom. Al' nije se moglo prenoćit'. A kad bi bilo završilo sve, u ponoć, u jedan sat, dva, išlo se svak' svojoj kući. ${ }^{118}$

Od Brinja do Krivoga Puta gostionice nije bilo, osim privatne kuće u Prokikama u kojoj je, prema kazivanjima, živjela pravoslavna obitelj koja je prodavala domaću rakiju. Te kuće danas više nema, a stanovništvo često to mjesto navodi kao ono kod Rože iz Krivog Puta, udate u Prokike. ${ }^{119}$ U gostionici u Krivome Putu moglo se popiti jeftinoga vina, onda bude, ajmo popit, onda bile su one litre velike, to su dupljaci se zvali. Onda se napiju pa se tako navale na kola i tako dodu kući. ${ }^{120}$

\footnotetext{
109 Mara Krmpotić Brnde, Veljun.

110 Vidi više o tome dalje u tekstu, u narednom poglavlju Trgovina i usluge izvan sajmova (Trajbari).

111 Vidi više o tome dalje u tekstu, u potpoglavlju Prodaja mlijeka - mljekarice.

112 Ivan Krmpotić iz Šojatskog Dolca: Mi (Šojatski Dolac) kad bi išli, mi smo u Brlogu imali prenoćište.

113 Ivan Butković Gara, Alan i Ivan Krmpotić, Šojatski Dolac.

114 Antun Prpić Matin, Veljun.

115 To je gostionica „Stric Luka“ u Senjskoj Dragi (Sveti Križ). Ista se gostionica spominje i u radu: BIRT et al., 2003:457 Podatak o gostionici „Stric Luka“, prilikom istraživanja 2004. godine, naveo je Ivan Krmpotić iz Šojatskog Dolca.

116 Milan Krmpotić Žutija, Veljun.

117 Vidi o tome u zasebnom poglavlju ove monografije, o tradicijskoj arhitekturi, autorice Ivane Šarić Žic.

118 Milan Tomljanović Periša, Zamalić.

119 Milan Krmpotić Žutija, Veljun.

120 Milan Tomljanović Periša, Zamalić.
} 


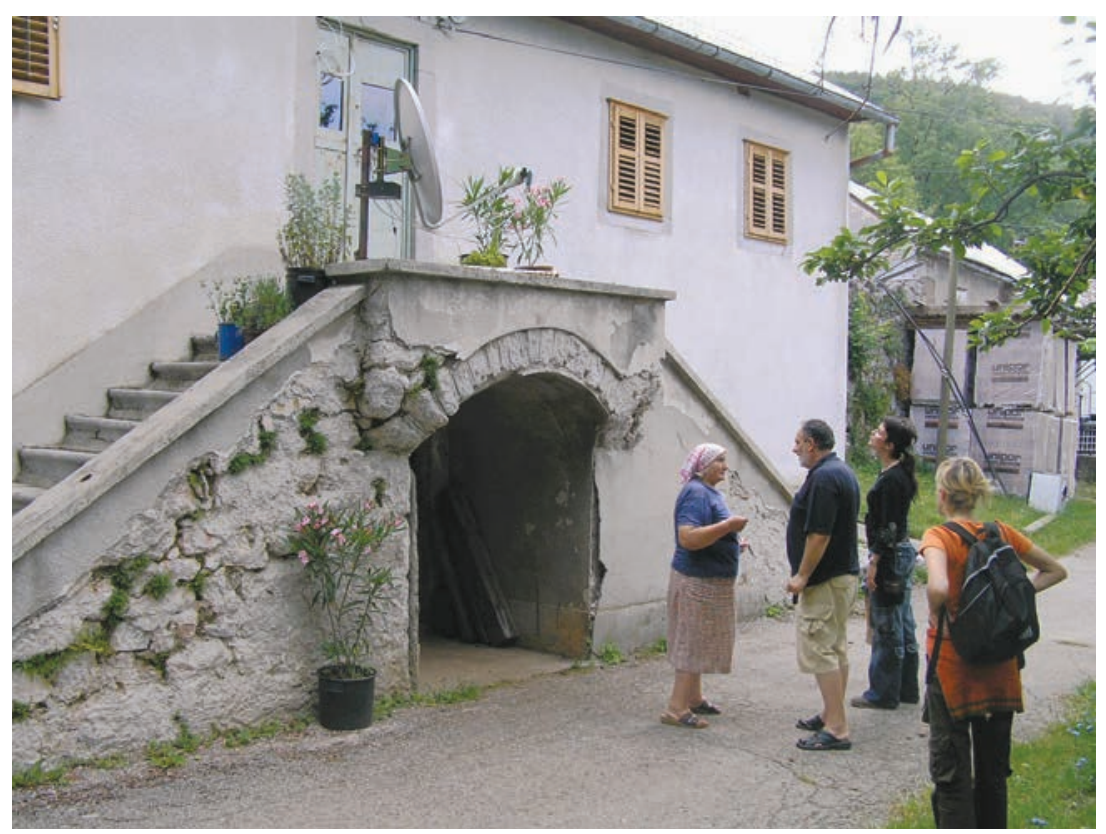

Slika 4: Francikovac, pred kućom obitelji Prpić Nikolčinih, u kojoj je bila gostionica. S lijeva na desno: Marija Prpić

Nikolčina, Mladen Šojat Bilin, Tibana Rubić i Sanja Lončar; snimila Marijeta Rajković, svibanj 2005.

Poznata i velika bila je gostionica u Francikovcu (Sl. 4), za koju krivoputsko stanovništvo često kaže: ona kod Pere Nikolića, trgovca stokom.

Danas u kući u kojoj je nekad bila gostionica živi bračni par Pere Prpić Nikolčin (čiji su djed i otac držali gostionicu) i Marija Prpić Nikolčina (Sl. 5). Prema njihovim riječima, iz Otočca i Udbine blago se gonilo do Francikovca, gdje je bila ta gostionica, u kojoj se moglo i prenoćit, malo popit $i$ onda su opet ujutro, rano, krenuli. ${ }^{121}$

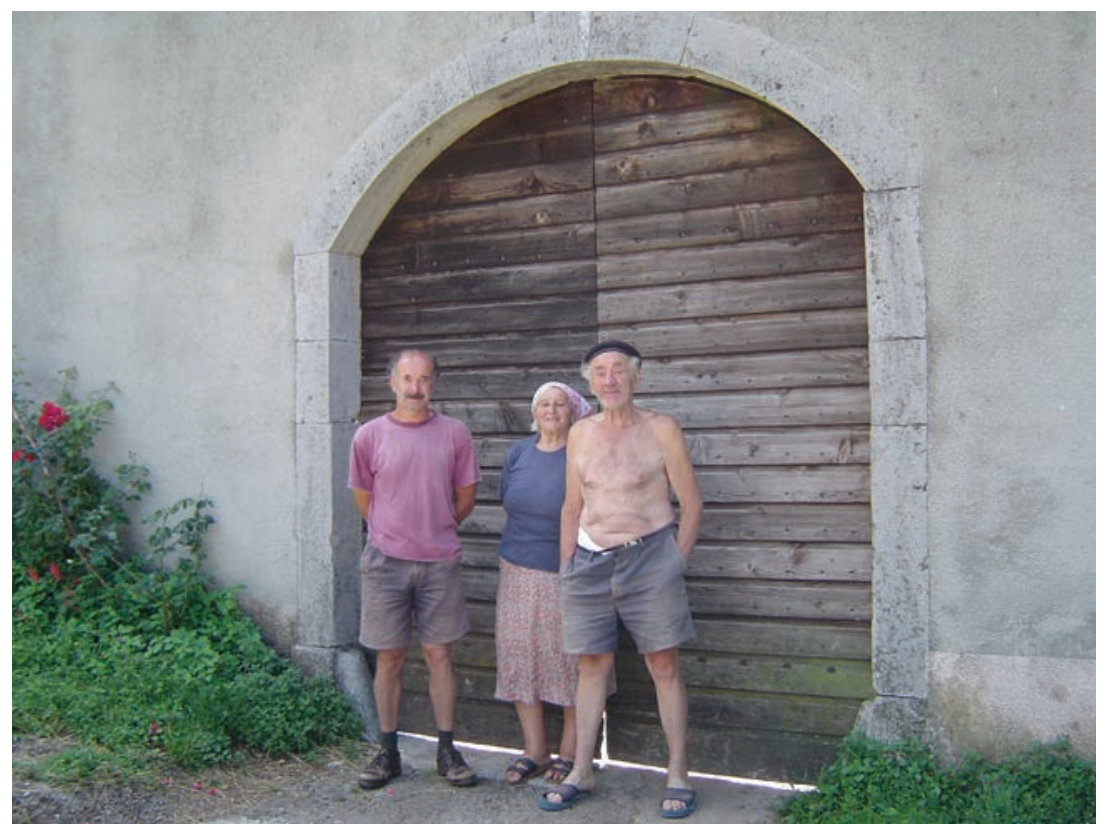

Slika 5: Francikovac, članovi obitelji Prpić Nikolčini pred glavnim ulazom u okućnicu u kojoj se nalaze gospodarske agrade.

S lijeva na desno: sin, Marija Prpić Nikolčina, Pere Prpić Nikolčin; snimila Tibana Rubić, svibanj 2005.

${ }_{121}$ Marija Prpić Nikolčina iz Francikovca, rodom iz Vrataruše. U daljnjem tekstu ovoj će kazivačici biti pridruživana dva lokaliteta: Francikovac (u kojemu živi) i Vrataruša (u kojem je rođena), obzirom na razdoblje o kojemu govori. 
Gostionica je imala ograđeni prostor za smještaj gonjenoga blaga i konja. I danas su, pred ulazom u gostionicu, vidljivi ostaci tora i velike ulazne volte, kao preostalih dijelova nekadašnjeg velikog građevnog sklopa za smještaj životinja (Sl. 6).

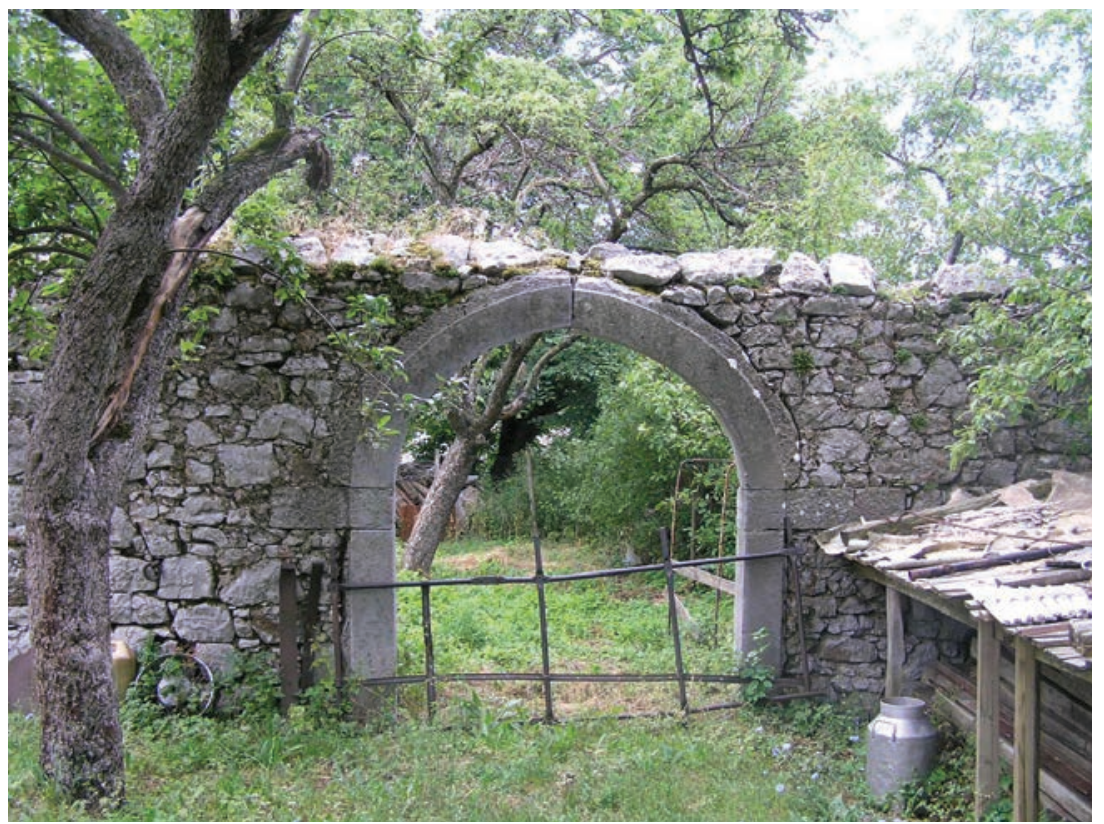

Slika 6: Francikovac, ulazni dio nekadašnjeg tora, koji se nalaæi pred kućom obitelji Prpić Nikolčinih; snimila Tihana Rubić, svibanj 2005.

U Krivome Putu je, prije Drugoga svjetskog rata, postojala i Gostiona Mijata Junca, kako je opisano jednim kazivanjem, koje bi narednim istraživanjima trebalo vremenski precizirati: davno prije, a on je bio vrlo bogat, jako veliku zemlju je imao. Bilo je tih stanica gdje bi ljudi mogli noćit, ako bi ih uhvatilo nevrijeme, snijeg, noć. Al pazite, oni su ga svi znali, nije on iša samo jedanput. Ti trajbari, on je iša tjedno. Najmanje tri put mjesečno u Rijeku. On je ima svoje stanice, njega su znali svi. Svoje konte gdi je on imao, gdi je noćivao, on je tu nešto i plaćao, ja vjerujem. To je tada funkcioniralo, kao željeznička stanica, tako je bilo kod njih uhodano. ${ }^{122}$

\section{TRGOVINA I USLUGE IZVAN SAJMOVA}

\subsection{TRAJBARI}

7 Tajbari su bili unajmljeni goniči blaga kupljenoga na sajmu. Blago je trebalo dogoniti, dognati, goniti 1 od sajma do određenog mjesta te su za taj posao bili plaćeni iskusni goniči stoke koji su se bavili isključivo tim poslom (trajbarijom). ${ }^{123}$ Trajbari nisu isto što i trgovci: Trajbari, to je drugo, različito od trgovaca. Trajbar je onaj koji goni trajbu za određenoga gazdu, on je trajbao za mesara određenoga ${ }^{124} \mathrm{Njihov}$ se rad posebno cijenio jer to su bili ljudi koji su znali to, nije bilo lako goniti sedam, osam, dvadeset, trideset volova. To treba sjediniti, goniti $i$ to nije bilo lako! ${ }^{125}$ Težina posla kojim su se bavili trajbari slikovito je opisana lokalnim kazivanjem: Onaj brat Ilija i mali je bio i onda oni upregnu 50 ovaca. Ćaća mu kupio na

\footnotetext{
122 Branko Tomljanović Ropeta, Krivi Put.

123 Milan Tomljanović Periša, Zamalić.

124 Rudolf Prpić Švorac, Podbilo.

125 Isti kazivač.
} 
sajmu u Otočcu ili u Brinju 50 ovaca, 10 volova, 6 krava, 5 magaraca, treba dognat to sve zajedno u Rijeku. Ovce idu svojim putom, guraju se, neće da idu, magarci svojim, krave svojim, trebalo je to. To je stvarno umijeće dognat u Rijeku da ti ne fali. ${ }^{126}$

Trajbari su trajbariju radili za vrijeme stare Jugoslavije, između dva rata, kad su vrlo često gonili krave, volove, junice iz Brinja i Otočca: Znali su platit čovjeka i to se pješice gonilo iz Brinja i Otočca na Škrljevo. To su najviše kupovali ovi pretršci takozvani, ti trgovci koji su znali po 50-60 volova kupit na sajmu. ${ }^{127}$ Otuda se blago utovarivalo na vlak i vozilo u Italiju, a vozilo bi se i okolo gore - po Lici, za Crikvenicu, ${ }^{128}$ pa doli priko Novoga, za Rijeku ${ }^{129}$ te iz Udbine do Trsta: Ja se sjećam kad su gonili za Rijeku i dalje. 'Izvor' se zvala ta klaonica, odma' je to u Rijeci tamo preko mosta. To su stari ljudi i pričali, baš da je iz ove kuće trgovac (Francikovac, njezina današnja kuća) i za Trst kupova.' ${ }^{130}$

Čovjek poznat pod špicnametom (nadimkom) Migec, rodom iz Veljuna, bio je jedan od trajbara, nakupac, koji je prethodno bio trajbar: Migec je bija nakupac za celu Rijeku. On je gonija, kupova po Brinju, Otočcu. Da, i on je bija trajbar jedno vrime dok nije postigao. A njegov je ćaća to najprvo počeo trajbariju $i$ onda posle i on je bija nakupac. Isli su tuda priko planina pa doli priko Novoga i za Rijeku. Dok nije posle auta, ${ }^{131}$ te u Francikovcu: S Veljuna, neki Migečevi, oni su gonili goveda pa i sestre od toga isto. Śpic-namet je Migec. Pa čak i u Trst su gonili, sa Udbine. Ja se sjećam bili su ti sa Veljuna. I sad ako želite otići taj je čovjek gore, a njegov otac se isto bavio. Isto je gonija. I njegova sestra. Gonili su goveda, tako da su znali prognat tu, gdje sam ja rodena (Vrataruša), ispred kuće moga oca. ${ }^{132}$

Blago se vrlo rijetko prodavalo u Senju. Prije pojave kamiona, između dva rata, kupljeno blago na sajmu bi pješice gonili trajbari. Dopremilo se blago u Šojatski Dolac, Francikovac i Veljun te sutradan u Senj gdje je bila klaonica na škveru gdi je sad kamp onaj, onda su otole po potrebi kolko bi trebalo blaga. Trajbar je ima tor ograden i tu im je dava jest, dok bi bilo blago kod njega. Onda bi oni po potrebi gonili to doli. Tako Ive isto, kad bi tu te bike, ima je štalu, tu (Šojatski Dolac) malo dalje od kuće, onda to baci u štalu i kad mu treba dođe i zakolje, prinoći dolje u hladnjači i sutradan kad mu treba meso, uzme i u Senj. ${ }^{133}$

I žene su mogle pomagati u trajbariji, baviti se gonjenjem stoke. Ta se pomoć uzimala kao način uštede novčanih davanja: Po dvojica idu, al' ako je on taj koji je gonija i ako je volija novac, onda nije uzeja pajdaša, nego je uzeo svoju ženu sa sobom. Pa su on i žena gonili pa su svi novci ostali u kući. I to ko je taj posa dobio, to je dobro bilo. ${ }^{134}$

\subsection{PRODAJA DRVA}

P rodaja drva nije se odvijala na sajmovima, već su se iz šumskih predjela krivoputskoga područja drva vozila u Senj, Sv. Juraj i Novi Vinodolski. ${ }^{135}$ Drva su se prevozila na prodaju u Senj iz mjesta: Šojatski Dolac, Veljun, Vratnik, Crni kal, Vodice i Miškovica.

Trupci bi se najprije pilili u šumskoj pilani u Alanu. ${ }^{136}$ Otuda bi se, dugi tri do četiri metra, vozili na kolima na prodaju u Senj ili Sv. Juraj. U pilani se plaćalo po kubiku drva ili kako se već tko pogo-

126 Branko Tomljanović Ropeta, Krivi Put.

127 Ante Prpić Rus, Rusova Draga.

128 Prpić Rudolf Švorac, Podbilo.

129 Ante Prpić Rus, Rusova Draga; Eleonora Prpić Hela, Veljun; Marija Prpić Nikolčina, Francikovac.

130 Marija Prpić Nikolčina, Francikovac.

131 Ante Prpić Rus, Rusova Draga.

132 Marija Prpić Nikolčina, Francikovac.

133 Ivan Krmpotić, Šojatski Dolac.

134 Milan Krmpotić Žutija, Veljun.

135 Isti kazivač.

136 Podatak o postojanju pilane u Alanu Marija Prpić Nikolčina je i vremenski odredila, rekavši: Ja sam se udala '57., a to je bilo ranije, možda desetak godina $i$ više, da su čak, pilana je bila na Alanu, drva su rezali, klade su rezali. Vidi o spomenutoj pilani također u zasebnom prilogu ove monografije, autorice B. Ljubović. 
dio s trgovcem. ${ }^{137}$ Oni koji su imali konje natovarili su kraće trupce (metar dužine) na konje te ih na samarima gonili u Senj. U Francikovcu i Veljunu volovi su služili za oranje, vuču sijena, ali i tovar drva. Iz navedenih bi se mjesta s natovarenim drvima kretalo uvečer kako bi se stiglo rano ujutro u Senj. S volima se nije moglo ići prečacem, tako da je put bio dug, a pored toga prodaja u Senju nije uvijek bila zajamčena pa bi se drva znala do sutradan ostaviti kod nekog poznatog u Senju. S druge strane, bilo je slučajeva da su se drva vozila isključivo po narudžbi: Svako je znao kome goni drva, jer taj kome je on naručio, taj je gonio. I sumnjam da ikad se ikome dogodilo da nije prodao. Jer to je po narudžbi bilo. Po tovaru, a ako se kolima, onda se to po tri, četiri, pet metri se vozilo to kolima drva za Senj. ${ }^{138}$ Oni koji su imali male konje morali su drva nositi na samarima, a s većim i jačim konjima vozila su se veća drva na kolima. ${ }^{139}$ Kočijaši, koji su imali svoje konje, vozili su drva i grede tjedno u Senj, a znali su prodavati i velike jarbole za brodove. U Senju bi nahranili konja i kupili vreću brašna, vina ili crnih šljiva.

U Senju je iza Drugoga svjetskog rata postojala i elektrana na drva, ovdje di sada parkiraju autobuse, kod Doma ovoga. ${ }^{140}$

Iz Veljuna su se drva na prodaju u Senj vozila na konjima ${ }^{141}$ ili magarcima. ${ }^{142} \mathrm{Na}$ magarcima su u Senj drva najčešće gonile žene koje bi se u Senj spuštale, primjerice, s Vratnika i iz Crnog Kala. Drva, otud dovožena, većinom su kupovali obrtnici privatnici, ${ }^{143}$ otkupivši metar do dva metra drva, na dug. Potom bi, prema riječima većine kazivača, svoj dug pošteno platili, jer nije bilo prevare ka' danas. Drva su se, katkad, u Senju i Jurjevu, mijenjala za hranu: brašno, šećer, sol, kavu i rižu.

Drva su se obično vozila ujesen jer je tada počinjala priprema za snabdijevanje drvima za ogrjev za zimu. ${ }^{144}$ Zabilježena su pojedina zanimljiva individualna iskustva prilikom gonjenja drva upopreko, iz Veljuna u Senj, nakon Drugoga svjetskog rata, s obzirom da se trgovina drvima mogla odvijati legalno i ilegalno. Drva su se sjekla u šumi onda i zatim na volovim ili na magarcim gonila u Senj. Na spomenutome putu do Senja bile su česte krađe prevažanih drva, stoga je bilo značajno održavati dobre odnose s lugarom koji bi, katkad, dozvolio da se prodaje i prevozi veća količina individualno posječenoga drva iz krivoputskih šuma, bez prijave i pribavljene dozvole: Ako te lugar uvati, onda ti zaplijeni. Nekad se i dogovorilo. Ja se sjećam, moj otac je, pokojni, vozio drva i on bi dogovorio u Senju kome će doć. Udu u dvorište po noći i trpaju. ${ }^{145}$

Kazivač iz Veljuna navodi kako je njegov otac prije Drugoga svjetskog rata prodavao drva, vukao sijeno i drva na prodaju u Senj: Natovariš na vole drva tri metara $i$ uveče kreneš i ujutro u Senju, kad vol sporo ide, on ide sporo, vi morete i marendovati i opet ga stignete (smije se). Tako je bilo. U po noći se kretalo, u po noći, ako bi stigao ujutro. Ha, ne moreš prečac, kako ćeś tri metara drva. Na koli. Nema préáaca. (smije se). Ja sam znao kol'ko puta, i moj pokojni stari, ima si grede to sad, za nekakve Bodule, onda nekad se prošverca. Mor'o si imat' izlaznicu od lugara, morao si imat' dokumente, onda si vozio slobodno. Negdi je lugar bija dobar pa je pustija, a negdi nije pustija. Pusti ga, na primjer, da malo više to posječe okolo. Ja se sjećam to je bilo kad bi lugar došao u kuću onda onim kobasicama se počasti lugara ${ }^{146}$. Nije u svaku kuću lugar dolazio, samo u odabrane kuće i onda mu se napravi jelo pa je gleda kroz prste malo. ${ }^{147}$

\footnotetext{
137 Prema kazivanju Ivana Butkovića Gare iz Alana.

138 Milan Tomljanović Periša iz Zamalića, iz vlastitog iskustva.

139 Ivan Butković Gara, Alan. Vidi o tome također u zasebnom prilogu ove monografije, autorice D. Birt.

140 Rudolf Prpić Švorac, Podbilo.

141 Milan Krmpotić Žutija i Antun Prpić, Veljun.

142 Prema riječima Milana Krmpotića iz Veljuna i Branka Tomljanovića Ropete iz Krivoga Puta. Vidi o tome opširnije u pripadajućem tematskom prilogu ove monografije, autorice D. Birt.

143 Milan Krmpotić Žutija, Veljun.

144 Milan Tomljanović Periša, Zamalić.

145 Kazivač iz Šojatskoga Dolca.

146 Podatak o mogućnosti pridobivanja lugara, no bez detaljnijih opisa, nalazimo i u literaturi (Grčević 2000:298).

147 Kazivač iz Veljuna.
} 
U Šojatskom Dolcu bilo je dosta ljudi koji su drva vozili na prodaju u Senj, još u drugoj polovici 20. stoljeća, no kako kaže kazivač iz Šojatskoga Dolca: to je pomrlo sve, tu iz ove kuće donje, gori i iz ove kuće $d v e^{148}$

\subsection{PRODAJA UGLJENA}

$\mathrm{N}^{2}$ a području Krivoga Puta postojao je zaselak Ugljevari, ${ }^{149}$ u kojem su se u šumi palili otpadci i od kojih se pravio ugljen. ${ }^{150}$ Prije i nakon Drugoga svjetskog rata, ugljen se prodavao kovačima u Krivome Putu, ${ }^{151}$ gore na Vodici, ${ }^{152}$ na Vratniku (dvojici kovača), Prokikama, ${ }^{153}$ u Drežnici ${ }^{154}$ i Lučanima, ${ }^{155}$ a ugljen se vozio, gonio, također i u grad Senj. Ugljenom su najprije bili snabdjeveni kovači, a zatim bi ga natovarili na kola i prodavali (po selima i u Senju). S obzirom da je ugljen bio prijeko potreban kovačima za njihov rad, prodaja ugljena nužno se vezivala uz opstojanje toga zanata. U trenutku kad kovači prestaju sa svojim radom (sedamdesetih godina 20. stoljeća), kad se pojavljuju tvornički proizvodi te nova prijevozna sredstva, koja isključuju postupno konje i kola, rad kovača prestaje biti potreban. Iz tog razloga istih godina prestaje i prodaja ugljena. Spominje se kako su ugljen nakon Drugoga svjetskog rata palili ovi gore sa Krivoga puta, koji su u tom poslu bili specijalisti $i$ znali su te ugljevarice delat $i$ palit. ${ }^{156}$ Odnosno, kako je zabilježeno u Veljunu: Ugljen se proizvodio gore, tamo od Krivog puta prema Paveliću, gdje su, kaže, bili sposobni za ugljen delat. ${ }^{157}$

\subsection{PRODAJA LEDA ${ }^{158}$}

Ta području Krivoga Puta ${ }^{159}$ zabilježeno je kako se iz mjesta Veljun ${ }^{160}$ i Šojatski Dolac ${ }^{161}$ led gonija na 1 prodaju u Senj ${ }^{162}$, kako prije, tako i nakon Drugoga svjetskog rata: tu je jedan čovjek bio, Špinići se zovu, ovde dolje ispod brijega, tu je on isto gonija led ${ }^{163}$, a prodajom leda se bavio i pokojni Brnde koji je ima snižnice na Veljunu i oko sedam-osam magaraca koji su gonili led u Senj, za mesnice i slastičare, jer nije bilo frižidera. To u Veljunu su bila njih dva koja su gonila. ${ }^{164}$

\footnotetext{
148 Ivan Krmpotić, Šojatski Dolac.

149 Trebalo bi provjeriti taj podatak i doznati o kojem se točno lokalitetu radi. Taj je podatak uočen tek naknadnim preslušavanjem lošije nasnimljenog razgovora nakon istraživanja 2004. godine, te je iz tog razloga na terenu ostao neprovjeren kod ostalih kazivača.

150 Ivan Butković Gara, Alan.

151 U Krivome Putu kovač je bio Stipe Kovač Prpić.

152 Rudolf Prpić Švorac, Podbilo i Milan Krmpotić Žutija, Veljun.

153 Milan Tomljanović Periša, Zamalić i Milan Krmpotić Žutija, Veljun.

${ }_{154}$ Milan Tomljanović Periša, Zamalić.

155 Ante Prpić Rus, Rusova Draga.

156 Ivan Krmpotić, Šojatski Dolac.

157 Milan Krmpotić Žutija, Veljun.

${ }_{158}$ O prodaji leda vidi također u prilogu o prehrani u drugom svesku Monografije, autorice J. Jurković.

159 Većina kazivača nije upitana na temu Prodaja leda jer se to pitanje vezivalo uz temu Transporta vodom, koju je istraživala kolegica Danijela Birt. No, kako je riječ o komunikaciji senjskoga zaleđa, naročito između lokaliteta Veljun i Šojatski Dolac sa Senjom (gdje se led prodavao), navodim u zasebnom odlomku i temu Prodaja leda, u okviru ovog poglavlja.

160 Rudolf Prpić Švorac, Podbilo.

${ }^{161}$ Ivan Krmpotić iz Šojatskog Dolca: Ovde (Šojatski Dolac) je bija jedan koji je sijekao taj led. Ime tog čovjeka u razgovoru nije precizirano.

${ }^{162}$ Ivan Krmpotić iz Šojatskog Dolca, Milan Krmpotić Žutija iz Veljuna, Marija Prpić Nikolčina iz Francikovca (spominje Donji Veljun).

${ }^{163}$ Ivan Krmpotić, Šojatski Dolac.

164 Rudolf Prpić Švorac, Podbilo; Milan Krmpotić Žutija, Veljun i Marija Prpić Nikolčina, Francikovac.
} 
Prodaja leda odvijala se na relaciji krivoputsko područje - Senj i također je zahtijevala cjelodnevni angažman: Natovare na blago ujutro rano te svoje sanduke na magarce il' konja, i so tim dole nizbrdo u Senj i ostav' to $i$ kupi stvari i ode kući. ${ }^{165}$ Posao gonjenja i prodaje leda nije bio lak ni izvjestan: Moraš prije dana bit u Senju, jer sunce ti rastopi i ode kapital kvragu! Ode sve! (smije se). Stoga je u poslove oko prodaje leda nerijetko bila uključena cijela obitelj, odnosno, bez naknade pomagala su i djeca: Tamo je taj Brnde, to je njegova proizvodnja bila. Onda bi on, ima je puno dice, oko dvadeset komada, onda bi to dica gonila, a on bi novce pobra. Deda je bio inkasator, a dica su radila. Nikakve plaće tu nije bilo. To je sve na veresiju (smije se). ${ }^{166}$

Snijeg bi se tijekom zime pohranjivao u velikim ${ }^{167}$ jamama, lokvama, ${ }^{168}$ snižnjačama, ${ }^{169}$ ledenama, ledanama ${ }^{170}$ prekriven bukovim lišćem (šušnjem) i granama ${ }^{171}$ kako bi se spriječilo otapanje leda. Snižnja$\check{c} a$ se iskopala u hladovini bukova drveća, koje bi dodatno štitila led od topljenja i to je morala bit velika jama iskopana medu bukvama, da bude hlad, da se ne topi. ${ }^{172} \mathrm{Na}$ jednoj je strani lokve mogla biti napravljena kamenica u koju se otapala voda i tu su vodu ljudi, koji nisu imali šternu, koristili kao pitku vodu. ${ }^{173}$ Tako pohranjeni, nabijeni ${ }^{174}$ snijeg, pretvarao se u led, koji bi se, prema potrebi sjekao ljeti te na konjima ili magarcima gonjao na prodaju mesarima i slastičarima u Senj.

\subsection{USLUGE KOVAČIJE}

Z

a veći broj lokaliteta postojao je jedan kovač kojemu su ljudi odlazili za potrebe potkivanja konja i volova ili nabavu poljoprivrednog alata. J. Čapo Žmegač, kako je već ranije spomenuto, piše o sajmovima kao povodu izlaženja iz vlastite lokalne zajednice te upravo ta međuseoska kretanja čine mreže seoske društvenosti (Čapo Žmegač 1998:251). Na taj način mogu se promatrati i kretanja prema određenim lokalitetima u kojima se nalazila kovačija, koja je šire područje u istom lokalitetu snabdijevala kovačkim uslugama. Na području Krivoga Puta stanovništvo ističe veliki značaj tog zanata.

$\mathrm{Na}$ Vratniku su kovačiju držala dva kovača, ali nisu bili orijentirani na kovanje dijelova konjske opreme, već na izradu dijelova alata te na potkivanje volova, dok je u Lučanima bio jedan kovač, izučen kod znamenitog kovača iz Krivoga Puta: Dašta su išli iz raznih mjesta u Vratnik! Tko nije im’o alat: Krivi Put, Francikovac išli smo mi i u Lučane tamo, gdi je bija kovač što je kod Stipe ovoga pokojnoga učija i njemu smo išli kovat poslije, kod Brinja tamo. ${ }^{175}$

Za čitavo područje Krivoga Puta postojao je jedan znameniti kovač imenom Stipe Prpić Kovač, u lokalitetu Krivi Put. ${ }^{176}$ Područje koje je on snabdijevao kovačkim uslugama je bilo vrlo široko: gravitiralo je ovde od Primorja do Brinjskog kraja, granice Brinjaka. ${ }^{177}$ Prema riječima jednog od kazivača, to se područje protezalo počevši ovde od Alana, Krmpota, onda tamo do Pavelića, pet hiljada stanovnika da je brojio! On je to meni za ručkom reka. ${ }^{178}$ Ljudi bi dolazili u kovačiju, naročito iz Alana, gdje je bilo puno kočijaša koji su radili na izvlačenju trupaca iz šume.

\footnotetext{
165 Rudolf Prpić Švorac, Podbilo.

166 Milan Krmpotić Žutija, Veljun.

167 Ivan Krmpotić iz Šojatskoga Dolca: Možda jedno deset sa deset.

168 Ivan Krmpotić iz Šojatskoga Dolca; Milan Krmpotić Žutija, Veljun; Marija Prpić Nikolčina iz Francikovca.

169 Marija Prpić Nikolčina iz Francikovca: Što ne bi sam snijeg napada, bi bura nanesla i oni bi to još više...

170 Marija Prpić Nikolčina, Francikovac.

171 Ivan Krmpotić iz Šojatskoga Dolca: Nisu borove metali jer bor ima miris, nego bukove grane.

172 Milan Krmpotić Žutija, Veljun.

173 Ivan Krmpotić iz Šojatskoga Dolca.

174 Milan Krmpotić Žutija: Cijelu zimu su djeca nabijala (smije se).

175 Ante Prpić Rus, Rusova Draga.

176 Nena Vukelić navodi podatak da je iz naziva zanimanja obitelj dobila i nadimak (špic-namet): Oni su potkivali konje $i$ oni, familiju zovu kao Kovače. Tako su ostali i nadimak.

177 Prema objašnjenju Ivana Butkovića Gare iz Alana.

178 Milan Tomljanović Periša, Zamalić.
} 
Stipe Kovač Prpić bio je tijekom dana zaposlen potkivanjem konja i volova te izrađivanjem kovanih dijelova za kola i alat. Pored potkivanja, Stipe je popravljao najraznovrsniji željezni alat za rad u polju: sjekire, motike, krampove i plugove. U Krivome Putu potkivao je i konje i volove, a za manje konje romski su putujući priučeni obrtnici, Cigani, skovali manje, jeftinije potkove, te ih prodavali na sajmu ili u selima. Kovači svoje proizvode nisu prodavali na sajmovima. Ispred kovačije spomenutoga kovača u Krivome Putu čekalo se na red i cijeli dan, ali konji za potkivat imali su prednost nad izradom kovanih dijelova za alat: Tako sam ja jednom dognao na magarcu k njemu kvake, špiceve i to. Onda je on mene zvao na ručak, al je reko: Ti ćeš, mali, morat čekat dugo, jer imam konje za potkivat. ${ }^{179}$

Kovačiju je, nakon Drugoga svjetskog rata, privremeno vodio Stipin sin Jure, ${ }^{180}$ kojega je otac naučio kovati i koji je povremeno kovao sve do preseljenja u Viroviticu, sedamdesetih godina 20. stoljeća. ${ }^{181}$ Nakon toga više nije bilo kovača u Krivome Putu. Sitne predmete još bi katkad za vlastite potrebe iskovali priučeni, samouki ljudi ${ }^{182}$ (plugove, motike i sl.) ili bi se još neko vrijeme odlazilo u Brinje, Prokike ili Drežnicu, ${ }^{183}$ dok i tamo postupno, do kraja sedamdesetih godina 20. stoljeća, kovačije nisu prestale $s$ radom, zbog starosti kovača i nestajanja potrebe za kovačkim proizvodima. Sedamdesetih godina 20. stoljeća ručno izrađeni proizvodi postupno su zamijenjeni jeftinijim tvorničkim proizvodima kojih se moglo kupiti u gradu Senju i na sajmovima u Brinju i Otočcu: tvornica je izbacivala i potkove i sve. I ovako poslije rata (Drugog svjetskog) to se sve promijenilo. Tako je i Stipina kovačija završila. ${ }^{184}$

\subsection{MLINOVI}

$\mathrm{M}$ linovi su nakon Drugoga svjetskog rata postojali u sljedećim lokalitetima: Žrnovnica, ${ }^{185}$ Brinje, ${ }^{186}$ Švica ${ }^{187}$ Brlog, ${ }^{188}$ Prokike ${ }^{189}$ i Klenovnica. ${ }^{190}$ Iz Alana i okolnih zaselaka išlo se na mlin u Žrnovnicu. ${ }^{191}$ Iz Rusove Drage, ${ }^{192}$ Krivoga Puta, ${ }^{193}$ i Veljuna ${ }^{194}$ odlazilo se na mlin u Brlog. ${ }^{195}$ Tamo je postojao

179 Isti kazivač.

180 O nastavljenom kovačkom poslu putem sina Jure podatak donosi Milan Tomljanović Periša: Onda se on njegov sin kao uz njega se učio. I bio je dobar potkivač i kovač, bio je dobar taj sin njegov.

181 Vidi više o migracijama u Viroviticu i okolicu u prilogu o migracijama u ovoj monografiji, autorice M. Rajković.

182 Milan Tomljanović Periša, Zamalić.

183 Budućim istraživanjima trebalo bi prikupiti podatke i o kovačima u Prokikama i Drežnici. Ispitani kazivači većinom su znali ime samo kovaču iz Krivoga Puta. Bilo bi vrijedno istražiti razlog - da li zbog toga što nisu gravitirali prema drugim mjestima radi usluga kovačije ili zato jer su ti drugi kovači djelovali ranije, a ne istovremeno s kovačem iz Krivoga Puta, čije bi djelovanje, kao i godinu prestanka rada i smrti trebalo vremenski precizirati u narednim istraživanjima.

184 Ivan Butković Gara, Alan.

185 Ivan Butković Gara, Alan; Milan Tomljanović Periša, Zamalić; Milan Krmpotić Žutija, Veljun; Zlata Tomljanović Pešina i Nena Vukelić, Krivi Put; Marija Prpić Nikolčina, Francikovac.

186 Milan Tomljanović Periša, Zamalić; Ante Prpić Rus, Rusova Draga; Mara Krmpotić Brnde, Veljun.

187 Mara Krmpotić Brnde, Veljun; Zlata Tomljanović Pešina, Marija Prpić Nikolčina, Francikovac.

188 Milan Krmpotić Žutija iz Veljuna: Mi (Veljun) smo nosili u Brlog; Marija Prpić Nikolčina, Francikovac; Branko Tomljanović Ropeta, Krivi Put; Ante Prpić Rus, Rusova Draga.

189 Mara Krmpotić Brnde, Veljun.

190 Milan Krmpotić Žutija, Veljun; Marija Prpić Nikolčina, Francikovac.

191 Ivan Butković Gara: Bilo je više tih i onda ste čekali, kad ste već napravili put, sačekali ste i onda ste donijeli kući. Ovamo kad bi se išlo, na primjer, u Otočac ili u Brinj, tamo je bilo i vode i mlinova onda usput i uzeo je ono što je imao i samljeo i već je obavio posao i vratio se. Milan Tomljanović Periša iz Zamalića blizu Alana također navodi podatak da je odlazio u Žrnovnicu na mlin.

192 Ivan Butković Gara, Alan.

193 Branko Tomljanović Ropeta, Krivi Put.

194 Milan Krmpotić Žutija, Veljun.

195 Ivan Butković Gara, Alan. 


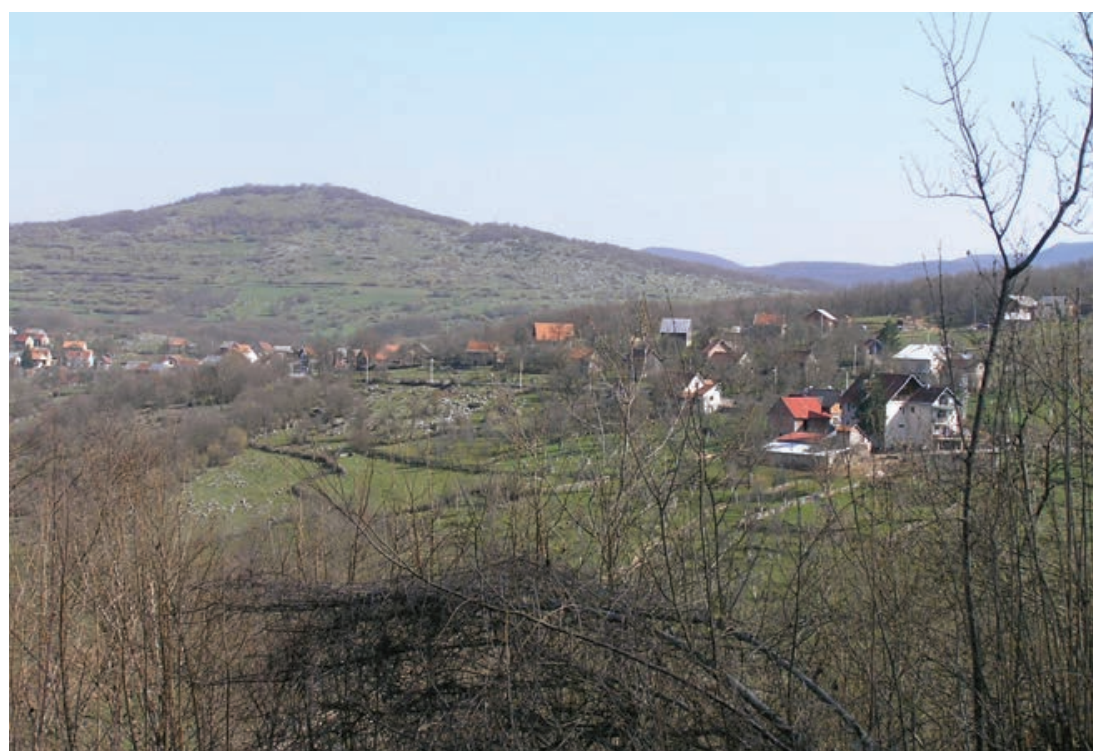

Slika 7: Švica, panorama; snimila Marijeta Rajković, lipanj 2005.

vodeni mlin, vodenica. Vodeni mlinovi bili su i u Brlogu, ${ }^{196}$ Žrnovnici i Švici (Sl. 7), u kojoj se nalazilo mnoštvo mlinova jer je gotovo svaka obitelj imala mlin. ${ }^{197}$

Premda su vodeni mlinovi sporiji te se moralo dugo čekati da se žito samelje (katkad i cijeli dan), većina stanovništva navodi kako se u vodenim mlinovima žito mljelo sitnije i kvalitetnije te se rade išlo na vodene, neg' na struju. ${ }^{198}$

Potreba za mljevenjem ječma, kukuruza ili žita bila je do Drugoga svjetskog rata velika: sijalo se žito, svak je ima svoju zemlju. Al' nije tu bilo za prodaju žita, nego za svoje potrebe. ${ }^{199}$ Kazivač iz Veljuna dao je slikovit opis jednog odlaska na mlin u Brlog: To ti se ovako - dodeš tamo i moraš čekat red, 'ko zna kolko je

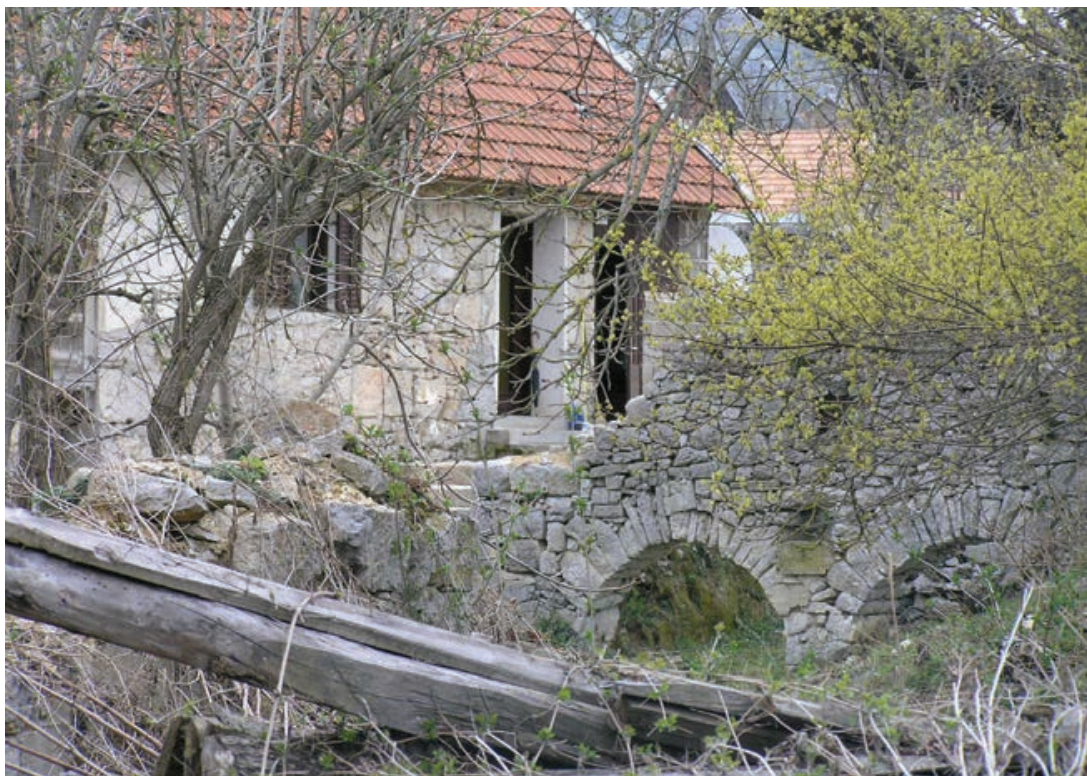

Slika 8: Švica, vidjivi ostaci zgrade u kojoj se nekad nalazio mlin i dijelova zida mostica; snimila Marijeta Rajković, listopad 2005.

\footnotetext{
196 Ante Prpić Rus, Rusova Draga, Milan Krmpotić Žutija, Veljun.

197 Zlata Tomljanović Pešina, Krivi Put.

198 Ista kazivačica.

199 Ante Prpić Rus, Rusova Draga.
} 
njih prid tobom. To smo mi gonili svoje žito. I kad dođeš na red. Znalo se bit po dva dana. ${ }^{200}$ Dava se ujam na mlinu. Vagan žita. Vagan je 45 kila. Ti moraš dat taj ujam. On ima tamo jedan sud $i$ toliko njemu što ti je on to samlija. On (mlinar) je mlija i uslugu vršija. Nije bilo ovih parnih mlinova, to su bili vodeni mlinovi. Na vodi. U Brlogu. Tri-četri mlina su bila tu tako. Onda bi mi koji ima vole, metnio u kola, povukla pa samlio, ko nema, na magarca pa pješice.

U Brinju su, iza Drugoga svjetskog rata, postavljeni električni mlinovi. ${ }^{201} \mathrm{U}$ mlin se na mljevenje nosilo i mlilo po nekoliko vreća, odmah poslije vršidbe, krajem kolovoza. Ponešto nesamljevenog zrnja žita i zobi ostavljalo bi se za kokoši, za konje i za sjeme, a ostalo bi se nosilo na mljevenje u mlin. ${ }^{202}$

\subsection{KUTAREVCI 203}

$\mathrm{K}$

uterevčani (Kuterervci, Kutarevci) su na području Krivoga Puta bili poznati i cijenjeni izrađivači i prodavači drvenih predmeta, drvenarije. Svoje su proizvode prodavali na sajmovima u Brinju i Otočcu (na krušnoj placi), ali i po selima krivoputskoga područja: Onda stane na selo i viče, tko će kupit, i ljudi izadu pa kupe, stolicu. ${ }^{204}$ Prodavali su i u gradu Senju, na mjestu gdje se moglo privezati i povjeriti na čuvanje konje: Na Malim vratima je bila štala gdje su konji bili i ako se šta proda, proda, ljudi su u prolazu šetali i ne’ko je kupio il’ nije. Tamo je bila konjušnica i štala $i$ štaler pa nisi nikakvog posla s konjima imao, samo njemu izruči i onda je on sijeno iz kola nosio i pojio. ${ }^{205} \mathrm{Na}$ sajmu u Brinju, primjerice, Kuterevčani bi prodavali svoje proizvode na krušnoj placi, dole, di su namirnice bile, na mostu, bez štandova, raspi ono svoje, sirotinja. Ne znam dal je netko imao odredeno mjesto svoje, nego kako je tho došao. ${ }^{206}$

Od kuterevačke drvenarije vrlo su poznate tamburice dangubice, instrument s četiri žice, ${ }^{207}$ ali i manje dangubice - igračke za djecu: ${ }^{208}$ Već se znalo da voze $i$ idu i djece je uvijek bilo pa idu sami, jure: Tata, kupi mi tamburicu! ${ }^{209}$ Osim toga, Kuterevčani su prodavali najrazličitije drvene proizvode: stolice (Sl. 9), ${ }^{210}$ stolčiće, ${ }^{211}$ žbanjice za vodu, ${ }^{212}$ burila, ${ }^{213}$ bačve, ${ }^{214}$ kable (sl. 10), škafi, ${ }^{215}$ (za pranje veša), lagve, ${ }^{216}$ kace za

200 Milan Krmpotić Žutija istaknuo je taj podatak, a Mara Krmpotić Brnde iz Veljuna također navodi kako se dugo čekalo na red: Dok ode ovako ko iz sela pa odemo skupa, natovarimo na magarce $i$ konje i bilo je puno naroda $i$ 'ko je prvi doša taj je mlija, a 'ko je zadnji, taj je čeka i onda po cijeli dan i navečer; Zlata Tomljanović Pešina iz Krivoga Puta: Puno je bilo, ljudi su svi išli pa ne bi moga doć na red, po nekolko dana, onda zavisilo je i o vodi, kako je vode bilo, kako je mlini su radili.

201 Ante Prpić Rus, Rusova Draga.

202 Branko Tomljanović Ropeta, Krivi Put.

203 Unatoč tome što je književni naziv Kuterevčani, lokalno i regionalno koristi termin: Kuterevci, Kutarevci.

204 Milan Tomljanović Periša, Zamalić.

205 Milan Tomljanović Periša, Zamalić.

206 Eleonora Prpić Hela, Veljun.

207 Rudolf Prpić Švorac, Podbilo; Milan Tomljanović Periša, Zamalić; Marija Prpić Nikolčina, Francikovac; Antun Prpić Matin, G. Veljun.

208 Ivan Butković Gara, Alan; Milan Tomljanović Periša, Zamalić; Marija Prpić Nikolčina, Francikovac: To su za odrasle bile, znali su to, znali su pojedini dobro i napravit, a bilo je i onih malih tamburica koje su si djeca svirala. Nisu svirali note, nego napamet.

209 Marija Prpić Nikolčina, Francikovac.

210 Ivan Butković Gara, Alan.

211 Milan Tomljanović Periša, Zamalić.

212 Ivan Butković Gara, Alan; Milan Tomljanović Periša, Zamalić; Marija Prpić Nikolčina, Francikovac.

213 Ivan Butković Gara, Alan; Milan Krmpotić Žutija, Veljun; Marija Prpić Nikolčina, Francikovac: Bilo je malih od 16 litara, sad 20, 30, kako je već tko uzimao.

214 Rudolf Prpić Švorac, Podbilo.

215 Marija Prpić Nikolčina, Francikovac.

216 Milan Krmpotić Žutija, Veljun. 


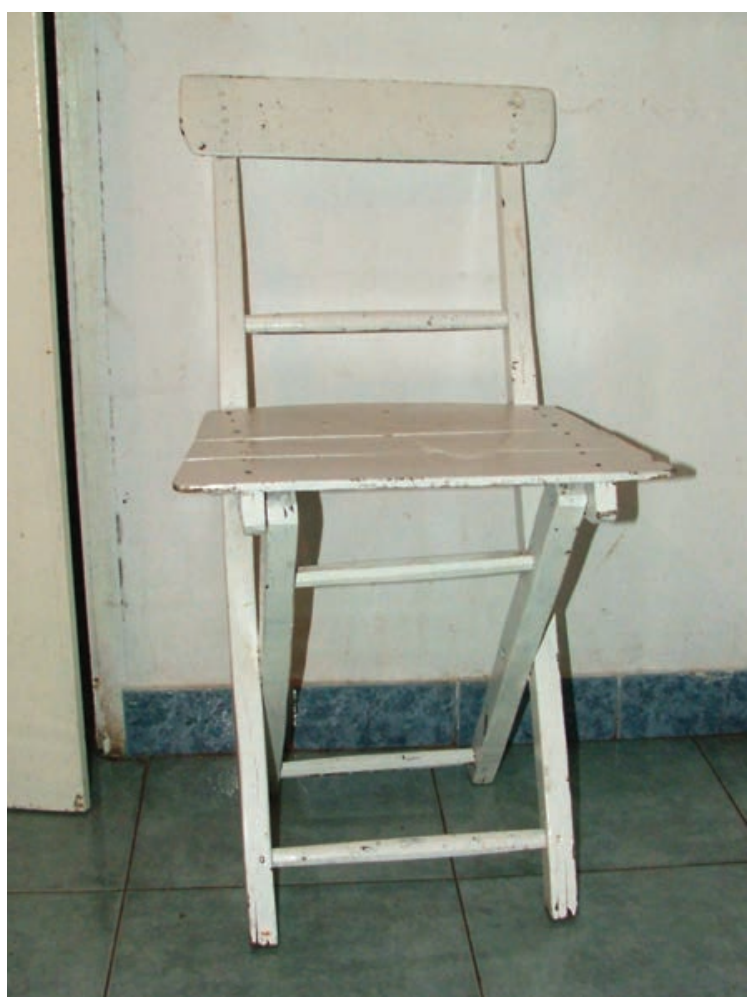

Slika 9: Krasno, primjer jednostavna i trajna drvenog stolca kakevog su rucno izradivali majstori iz Kutereva; snimila Tibana Rubic, srpanj 2005.

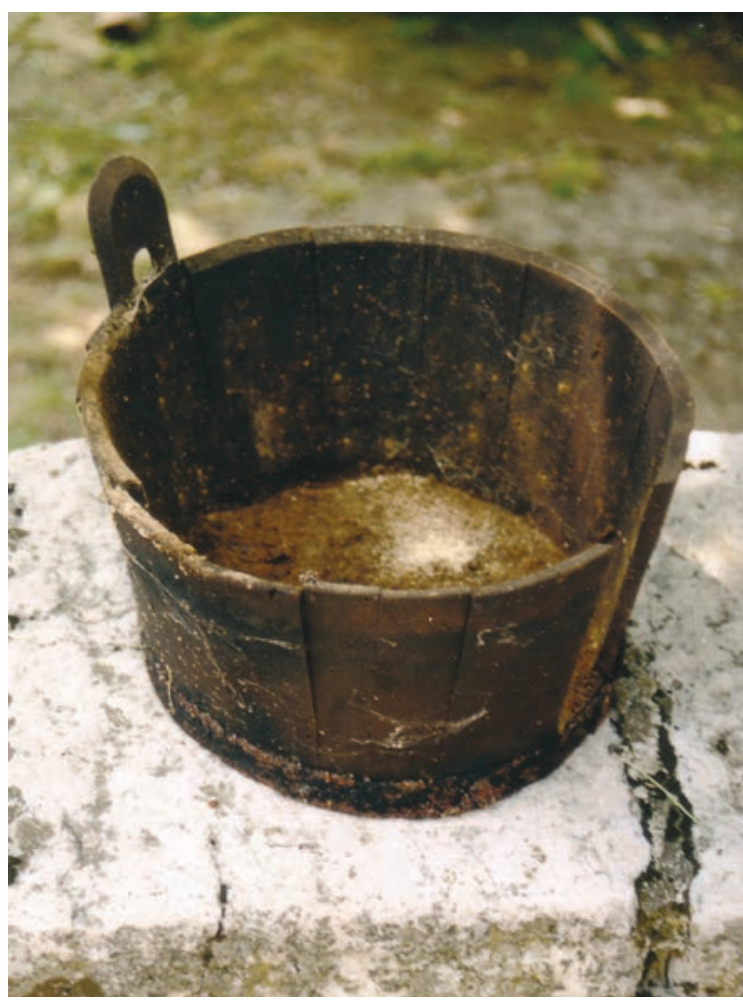

Slika 10: Kabao, koristio se prilikom mužnje mlijeka, primjer drvenog posuda kakvo su izradivali majstori iz.

Kutereva; snimio Augustin Peric, lipanj 2003.

zelje, ${ }^{217}$ raznorazna kosišta, ${ }^{218}$ stapove za mest mlijeko, ${ }^{219}$ a katkad i pletene korbače, ${ }^{220}$ kandžiluke ${ }^{221}$ (bičeve koje su koristili trajbari) te košare.222

Kuterevčani i danas prodaju drvenariju na sajmovima u Otočcu i Brinju te na zborovima ljeti, na spomen-dan Majke Božje Snježne (5. kolovoza), ${ }^{223}$ no najvećim dijelom ta drvenarija danas predstavlja suvenirsku ponudu koju se može kupiti na sajmu, s obzirom da je drveno posuđe u kućanstvu većinom zamijenjeno metalnim i plastičnim: Sve su to zanati koji umiru, al' još uvijek se nade ljudi koji prave bačvice, bukarice, stoličice, grablje, vile, alat, oruda, al' danas se sve to više-manje i nestaje. ${ }^{224}$

Vrlo često bi se ljudi unutar jednog sela dogovorili o tome što treba naručiti od Kuterevčana te bi jedan čovjek iz sela te proizvode naručio u Kuterevu ili bi kod Kuterevčana na sajmovima nabavljao proizvode za više njih te su se proizvodi u selo donosili prema narudžbi: To su dovlačili, tko je naručio bačvice, kablice male, stapove za mliko. Kad koji čovjek ide tamo (Kuterevo, sajam u Brinju ili Otočcu) iz našeg sela, onda naruči po njemu i onda oni (Kuterevčani) donesu. To bi se naručilo i to onda donesu. ${ }^{225}$

\footnotetext{
217 Ivan Butković Gara, Alan; Milan Krmpotić Žutija, Veljun.

218 Ivan Butković Gara, Alan.

219 Marija Prpić Nikolčina, Francikovac.

220 Ivan Butković Gara, Alan.

221 Branko Tomljanović Ropeta, Krivi Put.

222 Eleonora Prpić Hela, Veljun.

223 Mara Krmpotić Brnde, Veljun.

224 Nena Vukelić, Krivi Put.

225 Mara Krmpotić Brnde, Veljun.
} 
Svoje su proizvode, drvenariju, Kuterevčani vozili na kolima i obilazili područje senjskoga zaleđa i Primorja: U Senju bi bili dva-tri dana i otide dalje za Novi, za Crikvenicu. Oni su znali u Senj od Krivog Puta i Kutereva pa tamo do Novog i Bribira. Kad bi se natrag vraćali, ne bi se vraćali preko Alana, nego ovdje preko Butković Dolca. ${ }^{226}$

Stariji su Kuterevčani prenosili znanje i vještinu na mlađe muške članove obitelji koji bi im pomagali u poslu, a s vremenom bi obiteljski posao preuzeli i naslijedili. I žene (Kuterevčanke) znale su prodavati drvene proizvode, ${ }^{227}$ no puno rjeđe i najčešće kao pomoć muževima.

Svoje su proizvode Kuterevčani prodavali na sajmovima u Gospiću, Brinju, Otočcu i Udbini, po selima krivoputskoga područja ${ }^{228}$ i u gradu Senju ${ }^{229}$ (na Malim vratima). ${ }^{230}$ U Senju je na tom mjestu bila štala u kojoj su se mogli privezati konji: Toga je on puno mogao na kolima vozit, samo bi izložio robu. Tamo je bila konjuśnica $i$ štala $i$ štaler pa nisi nikakvog posla s konjima imao, samo izruči čovjeku u štali i onda je on sijeno iz kola nosio i pojio konje. Prodaja se odvijala i u Krasnom i okolici, zatim Švici, Kosinju, ${ }^{231}$ Ličkom Lešću, u Primorju, ${ }^{232}$ Slavoniji i čak Dalmaciji: ${ }^{233}$ Split, Zadar, Biograd, Makarska i Dubrovnik. ${ }^{234}$ Komunikacija Kuterevčana sa stanovništvom krivoputskoga područja zabilježena je u lokalitetima: Veljun, Francikovac, Krivi Put i Podbilo. S obzirom na udaljenost od tridesetak kilometara između Kutereva i krivoputskoga područja, Kuterevčani su na to područje drvenariju dopremali kolima ili manjim konjima.

Proizvodnjom i prodajom drvenih stolaca bavio se tek jedan dio Kuterevačana: (...) dio Kutereva, gore prema Pazarištu, ${ }^{235}$ dok su se u drugom dijelu Kutereva izrađivale bačve. Prilikom istraživanja u Kuterevu u travnju 2005. godine, Milan Malčić iz Kutereva, majstor koji cijeli život izrađuje drvene predmete, potvrdio je navedeni podatak rekavši: Kod nas su majstori: što su bili bačvari, su bili bačvari. I oni su samo bačve pravili, a koji su bili stolice, to su baš samo stolice pravili. Tako ovaj dio dole kod Šepaca (prezime: Šepac, više obitelji u Kuterevu), oni samo rade stolice, a ovaj krug, kod crkve, mi smo samo bačve. Tamburice su dole na kraj Kutereva, tu je pokojni jedan Šporčić umro (prezime: Šporčić, više obitelji u Kuterevu), ali ga je naslijedio njegov sin, koji sad ima 70 i nešto godina, a njega je opet nasljectiva Mirko koji ima sad 30-40 godina, Šporčić.

Kuterevčani i danas svoju drvenariju prodaju na sajmovima u Otočcu i Brinju, ${ }^{236}$ na zborovima u Krasnom ljeti, za Antunovo, ${ }^{237}$ te na spomen-dan Majke Božje Krasnarske: ${ }^{238}$ Da oni to i danas imaju koji rade. I stoličica koju ja imam, to nije staro kupljeno, tu nema ni pred šest godina da sam ja to kupila. Baš ću se sad ja sjetit kol'ko je koštala. Dvjesto kuna, nije puno koštala i to znam da je muž naručio bio. ${ }^{239}$ No, prodaja je danas pretežno orijentirana prema Dalmaciji gdje prodaju drvene bačve za vino. Za bliža okolna područja, primjerice Krasno, i danas se izrađuju i prodaju drveni stolci.

226 Milan Tomljanović Periša, Zamalić.

227 Mara Krmpotić Brnde, Veljun. Trebalo bi budućim istraživanjima detaljnije istražiti u kojoj mjeri su i u kojim prilikama žene sudjelovale u izradi i prodaji drvenih ili pletenih proizvoda iz Kutereva.

${ }^{228}$ Ivan Butković Gara, Alan.

229 Milan Tomljanović Periša, Zamalić.

${ }^{230}$ Milan Tomljanović Periša, Zamalić.

231 Zora Vukelić, Krasno: Kutarevci su dolazili u Krasno i Kosinj. Onda su od nas odlazili u Kosinj i Kutarevo, u Ličko Lešcé

232 Milan Malčić, Kuterevo, Marija Devčić, Krasno, Milan Tomljanović Perǐ̌a, Zamalić.

233 Jozo Grgić, Krasno.

234 Milan Malčić, Kuterevo.

235 Ivan Butković Gara, Alan.

${ }^{236}$ Nena Vukelić, Krivi Put.

237 Gostioničar nadimka Manjan, Krasno.

238 Nena Vukelić, Krivi Put.

239 Marija Devčić, Krasno. 


\subsection{TRGOVINA U GRADU SENJU}

U

prvoj polovici 20. stoljeća u Senju se kupovalo voće - grožđe i crne šljive: U Senju se kupovalo grožde i crne šljive. Gore kod nas (Krivi Put) nešto je bilo i šljiva, al' to su bile bijele šljive. To je bilo prvo vreme, za stare Jugoslavije, onda poslije su bili dućani. ${ }^{240}$ Kako je već ranije spomenuto, u vrijeme prije Drugoga svjetskog rata Bunjevci, povratnici s privremenog rada u Americi, otvarali su trgovine u Senju te istovremeno napuštali svoje rodne kuće u zaleđu. Na taj su način doseljeni Bunjevci sebi osiguravali egzistenciju u gradu, u kojem bi se tada trajno naselili. Trgovine su tako postajale mjestom doticaja doseljenika i građana Senja, koji su doseljene Bunjevce nazivali doklačencima. ${ }^{241}$ Sredstvo simboličkog razdvajanja među tim dvjema skupinama bio je prije svega govor i skup društveno i kulturno usvojenih normi, obrazaca ponašanja: Kad bi dobili kuću, napravili kuću i stacionirali se u Senju, onda su imali nekakav svoj mentalitet i svoj govor i rječnik u Senju, a mi imamo opet drugi, ovdje (u Senju) je bila čakavština, a kod nas (Krivi Put) je štokavština. ${ }^{242} \mathrm{U}$ trgovinama u Senju moglo se kupiti: sol, brašno, petrolej (petrolja), ulje, šećer i cigarete. ${ }^{243}$ Brašno je trebalo kupovati i u Senju jer je žito, koje se dobivalo vlastitom proizvodnjom na krševitom tlu, često bilo nedostatno za prehranu unutar jednog domaćinstva: Žitarica je vrlo malo bilo u našem kraju, a to što je i bilo, to nije dostajalo da bi čovjek prehranio familiju i sebe. ${ }^{244} \mathrm{Za}$ vrijeme Drugog svjetskog rata velik broj trgovina bio je zatvoren. Također, za vrijeme rata stanovništvo nije imalo čime platiti robu pa se u takvim okolnostima posezalo za razmjenom, koja je tada bila pretežit način pribavljana hrane. ${ }^{245}$ Dotad je svaka kuća imala mulu, magarca ili konja pa bi se u Senj najčešće odlazilo kolima te natovare brašna, vina $i$ tih sitnica $i$ zatim se pješice vraćaju gore. ${ }^{246}$ U Senju se kupovalo u trgovinama ponajviše za vrijeme stare Jugoslavije, a poslije Drugog svjetskog rata otvaraju se dućani i na području Krivoga Puta - u Podbilu i Alanu. ${ }^{247}$

Stanovnici otoka Krka i Raba, koje stanovništvo Krivoga Puta naziva onim Bodulima, odnosno, ti preko sa otoka dole, u Senju su prodavali, a i danas prodaju, voće (jabuke i grožđe) i paradajz. S udaljenijih otoka dolazili su, a i danas dolaze Dalmatinci koji prodaju: salatu, paradajz, mrkve, povrtlarstva, smokve, čak i sušene. I friške i sušene, ${ }^{248}$ zatim: vina, maslinovo ulje i maslinu. Bili su i oni korpari. To su Dalmatinci bili. On je prid sobom nosija korpu i tu je bilo nožića, lančića, prstenja onoga za dicu. Onda su vikali da je on - Mate, svi ga znate! ${ }^{249}$

Ličani su na prodaju ujesen u Senj donosili crne šljive, jabuke i krumpir. ${ }^{250}$

U Senju se mogla kupiti i riba, naročito prije Drugoga svjetskog rata, koja se prodavala kod nekadašnjeg (u Drugome svjetskom ratu porušenog) spomenika sv. Jurja. Riba se mogla kupiti i na tržnici gdje je bilo ribara Senjana. Bunjevke iz Vrataruše odlazile su svaki dan u Senj i ako bi trefile, ${ }^{251}$ kupile bi ribu pa donesle kući, onda se to peklo, tako da su one za ručak, za podne, već imale. ${ }^{252}$

\footnotetext{
240 Milan Tomljanović Periša, Zamalić.

241 Ivan Butković Gara, Alan.

242 Isti kazivač.

243 Antun Prpić Matin iz Veljuna navodi podatak da je za vrijeme, kako sam kaže, Titine i stare Jugoslavije u Senju bila tvornica cigara.

244 Antun Prpić Matin, Veljun.

245 Vidi više o razmjeni i u posebnom odlomku o nabavljanju soli.

246 Isti kazivač.

247 Milan Tomljanović Periša, Zamalić.

248 Ivan Butković Gara, Alan.

249 Antun Prpić Matin, Veljun.

250 Milan Tomljanović Periša iz Zamalića: Al' krumpir - to nismo kupovali, mi gore, jer mi smo gore svaki sadili sebi, za sebe krumpir, to su ovi Senjani kupovali, koji nisu imali gdje sadit.

251 Izraz trefile koristi se sa značenjem: zaradile prodajom mlijeka toga dana.

252 Marija Prpić Nikolčina, Vrataruša.
} 
Do Drugoga svjetskog rata u Senju se trgovalo i blagom koje bi bilo dognano u Senj i čiji su kupci bili sa otoka Raba i Krka: ${ }^{253}$ onda su ljudi čak dolazili po selim pa bi kupili kravu ili vola i gonili dole u Senj pa bi oni sa svojim brodicama odvlačili na Rab i Krk, odakle su donosili vino i svoje proizvode, grožde, pomidore, što je ranije dole dozrijevalo, vino, rakiju. U Senju je bila i placa na koju je cijela Lika vozila u Senj, ${ }^{254}$ a tamo su se prodavale različite prehrambene namirnice, primjerice, kupus, krumpir i orasi. U Senj su dolazili oni iz Klenovnice, iz Primorja, oni Boduli, koji su donosili smokve i ribu. Stanovnici senjskog zaleđa bi na tu placu donosili domaći sir škripavac. ${ }^{255}$

\subsection{NABAVLJANJE SOLI}

Sol se naročito potraživala i razmjenjivala u vrijeme Drugoga svjetskog rata. Tijekom rata se, za do$\checkmark$ bivanje soli, iskuhavala morska voda. ${ }^{256}$ Nakon toga su u Senju uz more izgrađeni soleni magazini, gdje su trgovci nabavljali sol i vozili je na prodaju u Karlovac. Sol se, sve do Drugoga svjetskog rata, dovozila pretežno s otoka Paga, odakle su se na prodaju u Senj dovozili i brašno i petrolej. Sol sa susjednih otoka mijenjala se i za brašno, žito i pšenicu. ${ }^{257}$ Razmjena se, općenito, tijekom ratnih godina, vršila i sa Slavonijom kamo se odlazilo iz krivoputskoga područja i predjela u zaleđu Rijeke: Prije kod nas nije bilo te razmjene, al'u ratu je bilo, čisto radi, da ostane nekako snabdjeven, da ne bude gladan. Sa Slavonijom, najviše sa Slavonijom. Čak to smo mi i zvali, Kirice. Dole prema Crikvenici dole, oko Gorskog kotara, kukuruza na leda metni i nosi prě́acima. Kirice, te gore, iza Grobnika, kod Crikvenice, Grižane. To su nosile gore u Slavoniju soli i ovo, a donosile kući taj kukuruz. ${ }^{258} \mathrm{U}$ kontinentalnim krajevima Hrvatske u ratu je tako bila i velika nestašica soli pa se iz Senja sol švercala u Slavoniju, vlakom do Josipdola, zatim kamionima preko Kapele. ${ }^{259}$ To nije bila trgovina jer trgovci u ratnim prilikama nisu mogli slobodno trgovati te novaca, općenito, nije bilo. Bunjevci su pojedinačno odlazili u Slavoniju, skrivajući se od vojske, i tako vršili razmjenu proizvoda. Za sol su se dobivali pšenica, ${ }^{260}$ kukuruz $^{261}$ ili krumpir. ${ }^{262}$

\subsection{PRODAJA MLIJEKA, MLJEKARICE}

$\mathrm{B}$ unjevke mljekarice, mlekarice, mlikarice su, s čitavog područja Krivoga Puta, do iza Drugoga svjetskog rata, dnevno prodavale kravlje mlijeko svojim stalnim mušterijama (kontama) u gradu Senju.

Natovarile bi $d v i$, tri ciplice $d r v a^{263}$ na magarca s obje strane is velikim se posudama punim mlijeka, rano u zoru (četiri sata ujutro), ustaljenim putovima i prečacima s Krivoga Puta spuštale u grad Senj. Pred vratima svojih konti prelivale bi mliko iz svojih plehnatih kantica i mjerica. Do osam sati ujutro već bi svo mliko bilo razdijeljeno: imale su plehnate kante i mjerice, pola litre, dva deci, onda bi one stim mjericama nama lijevale u te kotlice ${ }^{264}$

253 Ista kazivačica.

254 Antun Prpić Matin, Veljun.

255 Zlata Tomljanović Pešina, Krivi Put.

256 Milan Tomljanović Periša iz Zamalića i Milan Krmpotić Žutija iz Veljuna.

257 Nena Vukelić i Zlata Tomljanović Pešina iz Krivoga Puta; Marija Prpić Nikolčina iz Vrataruše.

258 Ivan Butković Gara, Alan.

259 Milan Tomljanović Periša, Zamalić.

260 Ivan Butković Gara, Alan; Milan Tomljanović Periša, Zamalić i Ante Prpić Rus, Rusova Draga.

261 Ivan Butković Gara iz Alana i Milan Tomljanović Periša iz Zamalića naveli su kukuruz, a Milan Tomljanović Periša naveo je i podatak o razmjeni soli za kukuruz i obratno, na relaciji Slavonija - Senj.

262 Ante Prpić Rus, Rusova Draga.

263 Milan Krmpotić Žutija, Veljun.

264 Nene Vukelić, Krivi Put. 
Uz mlijeko su prodavale: škripavac (sir), ruksak krumpira, ${ }^{265}$ jaja, putar, kiselinu i tovar drva, ${ }^{266}$ živu kokoš, slaninu, korabu, grah, povrće, $i$ sve drugo što su imale za donest. ${ }^{267}$

Za prodane proizvode mljekarice bi u Senju kupile palentu, ${ }^{268}$ ribu, ${ }^{269} \mathrm{kruh}, \mathrm{s}$ sećer, ${ }^{270}$ duvan za muža (cigare) ${ }^{271}$ i malo kave, ${ }^{272}$ te se prečicama uzbrdo vraćale kući: mora si hodat, nisi ima od čega živit. ${ }^{273} \mathrm{Na}-$ brajajući proizvode koje bi žene nabavljale u Senju, kazivač iz Krivoga Puta ističe i težinu posla i općenito tadašnjeg načina života: To bi kupila eventualno i došla bi kući, skuhala ručak i tako je to išlo. To je bio dosta težak posa', mukotrpan je to posa' bio, neponovilo se taj način života! ${ }^{274}$

Nakon što je Poljoprivredna zadruga, nakon Drugoga svjetskog rata, formirala otkupnu stanicu na Krivome Putu, mljekarice su postupno prestajale prodavati mlijeko u Senju i orijentirale se na prodaju na otkupnoj stanici: Mnogi ljudi su se orijentirali na mljekarstvo, nisu više išli u svijet da rade, jer su mogli živjet od prodaje, a mljekarice su uvijek nešto nosile, tho je imao višak, zadruga je organizirala otkup, čak smo bili organizirali i otkup ljekovitog bilja. ${ }^{275}$

Otkup mlijeka za područje Krivoga Puta počeo je šezdesetih godina 20. stoljeća. Od tada su, primjerice, žene iz Klarićevca i Primorja donosile mlijeko na otkupnu stanicu jer više se isplatilo što nisi tam (u Senju) dangubio. Dođe ujutro i tamo (na otkupnoj stanici) salije mlijeko u te kante i onda si išao kući svojoj, svoj drugi posao koji si trebao. ${ }^{276} \mathrm{Na}$ otkupnoj su se stanici također prodavala jaja i kokoši koje su kupovali oni koji ih nisu imali ili su ih imali malo.

Mljekarice su, prije osnivanja otkupne stanice u Podbilu, dolazile iz Alana, Podbila, Krivoga Puta, Katića i Pavelića. Puno mljekarica spuštalo se u Senj i iz Veljuna i Vrataruše. ${ }^{277}$ Eleonora Prpić Hela iz Krivoga Puta donosi zanimljivo kazivanje o tome kako je prodaja koju su ostvarivale mljekarice bila vrlo skromna: Baba koja bi donesla možda par jaja, koju bocu mlika, to nije bila baš bogzna kakva trgovina, to je bila škrti kraj, škrta zemlja, ajd bog da su i sebe snabdijevali, da se nisu zaduživali, to je jako bilo skromno, ili kako opisuje Nena Vukelić: Nije to bila velika prodaja, to je višse bilo odvajanje od svoje obitelji, nisu se oni bavili proizvodnjom toga, nego sad višak ili nužda natjera pa ide prodat kokoš, već što je imala.

U Senju su mljekarice tamo kod male crkvice dolazile iz sela i zaselaka krivoputskoga područja dok nije iza rata (Drugog svjetskog) došla mljekara i preradivalo se. ${ }^{278}$

Najslikovitiji opis dnevnoga posla koji su mljekarice obavljale, predočila je kazivačica iz Francikovca, rodom iz Vrataruše, koja je zanimljivo iznijela vlastita sjećanja na prodaju mlijeka kojom se bavila njezina majka. U prodaju bi se odlazilo ljeti svaki dan, odnosno, zimi svaki drugi dan: Nije Senj veliki bio, bilo je stanovništva okolo, al' poslije se to iselilo. Tamo su, u Senju, prodavale. Nije bilo frižidera pa su mljekarice morale ić, oće-neće, ili su mlijeko trebale zakuhati. Održavanje kvalitete mlijeka bilo je preduvjetom za zadržavanje stalnih mušterija (konti) u Senju: Ako nisi danas dobro mlijeko, sutra je mušterija našla drugu. Morale su zadržati čistoćom mušterije. Sjećam se, bio je kod nas jedan muškarac u selu i on jadan, opere ma-

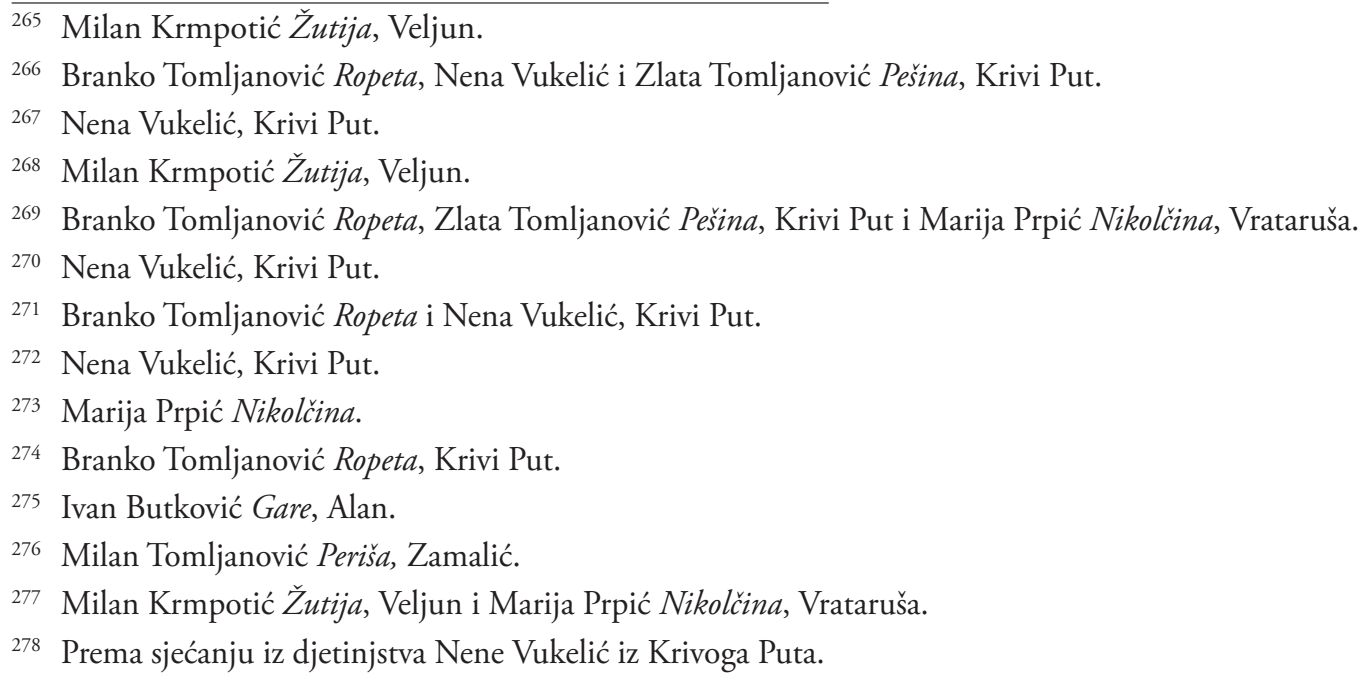


ramice i nije brisa’ nos dok nije doša u grad, izlio mlijeko i onda bi izvadio čistu maramicu pa se obriso da se vidi da je ta maramica, i on, čist. Mlijeko se u Senj nosilo rano u zoru i ostavljalo bi se mušterijama na kućnome pragu: Ako su spavali, to su većinom gospoda bila, onda su ostavile svoju posudu, litru ili politru i onda se to izlilo i ode ća. Neke su znale, koje su dobre bile (mušterije), malo mljekaricu i počastit s nečim, malo rakije ili kolač. ${ }^{279}$

Zarada mljekarica od prodaje mlijeka bila je skromna: Nije se to puno moglo prodat, ako je neko nešta ima, to je više za sebe ima, a ako je neko ima viška, onda je nosio, prodao. Ako se sir i putar pravio, nije se moglo mlijeko prodavat, nisu to krave bile koje su puno mlijeka davale, nego to su bušice, krave koje su najviše davale možda 6-8 litara mlijeka ${ }^{280}$.

\subsection{OTKUPNA STANICA U PODBILU NA KRIVOME PUTU}

Tekoliko godina nakon Drugoga svjetskog rata u Podbilu je osnovana Opća poljoprivredna zadruga 1 Krivi put. Zadruga je sve do druge polovice sedamdesetih godina 20. stoljeća vršila otkup blaga i mlijeka za čitavo područje Krivoga Puta.

Otkup se na otkupnoj stanici pored crkve održavao jedanput tjedno, petkom. Osnivanje Zadružne otkupne stanice djelomično je preorijentiralo prodaju blaga i mlijeka sa sajmova i Senja na Podbilo, gdje je Zadruga obavljala otkup blaga i mlijeka. Bunjevke mljekarice iz krivoputskoga područja tako su postupno prestale prodavati mlijeko u Senju.

Po osnivanju spomenute Zadružne otkupne stanice mljekarice su, kao i Bunjevci svoje blago, mlijeko donosile iz okolnih sela i zaselaka Krivoga Puta na otkup u Podbilo. Zadruga je otkupljivala mlijeko po litri, kao mjernoj jedinici i prema masnoći, kao ocjeni kvalitete. Kako bi se zaštitila od pokušaja razrjeđivanja mlijeka vodom, Zadruga je ubrzo uvela precizno mjerenje masnoće pomoću laktodecimetra.

Zadruga je, pored otkupa mlijeka, obavljala i selekciju stoke. Prije Drugoga svjetskog rata na krivoputskome je području prevladavala krava buša, pasmina najprikladnija za krški kraj, koja daje vrlo malo mlijeka (8-10 litara). Osnivanjem Zadruge postupno se napušta uzgoj navedene pasmine te se iz Slovenije i Slavonije dovodi nova montafonac pasmina, koja je davala 15 do 20 litara mlijeka. Tu je pasminu Zadruga intenzivno otkupljivala na otkupnoj stanici u Podbilu. ${ }^{281}$ Dotjerivanje blaga na otkupnu stanicu nazivalo se dogon. ${ }^{282}$

Ivan Butković Gara iz Alana, bivši upravitelj Zadruge, ${ }^{283}$ prisjeća se kako su se na poticaj Zadruge, nakon Drugoga svjetskog rata, Bunjevci s krivoputskoga područja orijentirali na proizvodnju mlijeka, čime je Zadruga utjecala, prema njegovu mišljenju i na smanjenje učestalosti iseljavanja s tog područja. ${ }^{284}$ No, Zadruga postupno prestaje s radom upravo zbog raseljavanja stanovništva iz područja Krivoga Puta i senjskog zaleđa, naročito u grad Senj, koje je intenzivnije nastupilo sedamdesetih godina, ali je započelo već šezdesetih godina 20. stoljeća: Sve je išlo normalno sa Zadrugom negdje do '68. godine. To je bio prelom, kad je počelo raseljavanje. ${ }^{285}$

\footnotetext{
279 Marija Prpić Nikolčina, Vrataruša.

280 Marija Prpić Nikolčina rodom iz Vrataruše.

281 Ivan Butković Gara naveo je kako je postojala otkupna stanica (ali od druge zadruge) na Vratniku. Osim njega ni jedan kazivač nije spomenuo otkupnu stanicu na Vratniku pa se može pretpostaviti da se iz istraženih lokaliteta nije tamo odlazilo, već da je stanovništvo općine Krivi Put bilo orijentirano na otkupnu stanicu u Podbilu. No, taj bi podatak svakako trebalo provjeriti.

282 Milan Tomljanović Periša, Zamalić.

283 Ivan Butković Gara iz Alana bio je upraviteljem Zadruge od 1957. do 1976. godine. Rudolf Prpić Švorac iz Podbila naveo je ime pokojnog Ivice Prpića - bivšeg upravitelja Zadruge, no nije se mogao prisjetiti kojih je godina bio upraviteljem Zadruge.

284 Vidi o tome više u zasebnom prilogu ove monografije, autorice M. Rajković.

285 Ivan Butković Gara, Alan.
} 


\section{ZAKLJUČAK}

$\mathrm{N}$ a području Krivoga Puta, u razdoblju prije i nakon Drugoga svjetskog rata te pretežito do sedamdesetih godina 20. stoljeća, trgovina je činila važnu mrežu komunikacijskih kanala Bunjevaca krivoputskoga područja s drugim etničkim, vjerskim i klasnim zajednicama u bližem i udaljenijem zemljopisnom području. Trgovina i snabdijevanje neophodnim proizvodima i blagom vrlo su često bili isključivi razlozi izlaska iz lokalne zajednice te jedini kontinuirani doticaj Bunjevaca krivoputskoga područja sa stanovništvom grada Senja. Istraživanje trgovinskih kretanja, usluga i razmjene dobara predstavlja stoga značajno polazište za bilo kakvo detaljnije utvrđivanje (razloga i načina) međumjesnih i međuregionalnih komunikacija, za koje možemo pretpostaviti da su imale udjela i u oblikovanju identiteta Bunjevaca krivoputskog područja.

Upravo su razmjena dobara i snabdijevanje proizvodima sa sajmova i izvan njih bili jedan od značajnijih segmenata koji su (se) odražavali (na) svakodnevni život Bunjevaca iz područja općine Krivi Put, s obzirom na uglavnom krševito, siromašno i slabo rodno tlo senjskoga zaleđa na kojemu su živjeli. Takvi prirodni uvjeti katkad nisu mogli zadovoljiti čak ni osnovne prehrambene, odjevne i inventarne potrebe jednog domaćinstva, stoga je trgovina bila jedan od nužnih povoda izlaska iz matičnoga zemljopisnoga područja, u svrhu pribavljanja proizvoda kojih u okviru tog područja nedostaje. Stoga se u ovom prilogu naglasak pokušao staviti na praćenje puteva i kretanja prema određenim lokalitetima na području općine Krivi Put te izvan nje. Ta su kretanja potaknuta trgovinskom razmjenom dobara na sajmovima i izvan njih. Odlasci na sajmove, primjerice na relacijama: sela krivoputskog područja - Otočac, sela krivoputskog područja - Brinje, te trgovina koja je upućivala ljude na dnevna kretanja izvan vlastite lokalne zajednice: sela krivoputskog područja - Senj, predstavljali su živ segment ukupnoga života Bunjevaca krivoputskoga područja prije i poslije Drugoga svjetskog rata te ponajviše do sedamdesetih godina 20. stoljeća.

\section{LITERATURA}

ČAPO ŽMEGAČ, Jasna (1998): Seoski prostor kao osnovni prostor društvenosti U: ur., Vitomir Belaj, Jasna Čapo Žmegač, Jadranka Grbić, Muraj Aleksandra, Zorica Vitez, Hrvatska etnografija, Svagdan i blagdan hrvatskog puka, Zagreb, 271-284.

ČERNELIĆ Milana (2000b): Dvije zadružne obitelji na području Krivoga Puta. Senjski zbornik, 27, Senj, 199-216.

GRČEVIĆ, Jure (2000): Trgovina. U: Jure Grčević, Kompolje. Narodni život i običaji, Kompolje, 297-298.

HEĆIMOVIĆ-SESELJA, Mara (1985): Tradicijski život i kultura ličkoga sela Ivčević Kosa, Zagreb.

MURAJ, Aleksandra (1990): Alternativno trgovanje između potrebe i razonode. Etnološka tribina, 13, Zagreb, 33-40.

MURAJ, Aleksandra (1998): Obradba kože i roga. U: ur. Vitomir Belaj, Jasna Čapo Žmegač, Jadranka Grbić, Muraj Aleksandra, Zorica Vitez, Hrvatska etnografija, Svagdan i blagdan hrvatskog puka, Zagreb, 95-97.

MURAJ, Aleksandra (2001): Prehrambene tradicije. U: ur. Aleksandra Muraj i Zorica Vitez, Hrvatska tradicijsk kultura na razmedu svjetova $i$ epoha, Zagreb, 295-308.

RUBIĆ, Tihana (2004): Trgovina i sajmovi. Rezultati istraživanja na području općine Krivi Put. Senjski zbornik, 31:287-324, Senj.

RUKAVINA, Ante (1993a): Senj i senjski predjeli u županijskim sustavima i osvrt na razvoj stočarstva i veterinarstva u tim predjelima. Senjski zbornik, 20, Senj, 215-218.

RUKAVINA, Ante (1993b): Osvrt na razvoj stočarstva i veterinarstva u Lici i Podgorju. Senjski zbornik, 20, Senj, 219-224. 
SUPEK, OLGA (1987): Darivanje kao totalna komunikacija, Etnološka tribina, 10:7-18, Zagreb.

ŠKRBIĆ-ALEMPIJEVIĆ, Nevena (2003): Prilozi poznavanju primorsko-bunjevačkog identiteta. Senjski zbornik, 30:425-444, Senj.

\section{IZVOR}

Upitnica Etnološkog atlasa (UEA), Tema br. 105: Sajmovi (Vašari), Fd 422/562 (Vratnik) i Fd 434/1785 (Jurjevo), Arhiv Odsjeka za etnologiju i kulturnu antropologiju, Filozofski fakultet u Zagrebu. 